\title{
Evolution of the phytoplankton assemblage in a long-lived mesoscale eddy in the eastern Gulf of Alaska
}

\author{
Tawnya D. Peterson ${ }^{1,2, *}$, David W. Crawford ${ }^{3}$, Paul J. Harrison ${ }^{4}$ \\ ${ }^{1}$ Science and Technology Center for Coastal Margin Observation and Prediction and ${ }^{2}$ Division of Environmental \\ and Biomolecular Systems of the Institute of Environmental Health, Oregon Health \& Sciences University, \\ Beaverton, Oregon 97006, USA \\ ${ }^{3}$ Department of Biology, University of Victoria, Victoria, British Columbia V8W 3N5, Canada \\ ${ }^{4}$ Department of Earth \& Ocean Sciences, University of British Columbia, 2146 Health Sciences Mall, Vancouver, \\ British Columbia V6T 1Z3, Canada
}

\begin{abstract}
We tracked changes in the phytoplankton species composition in an anticyclonic mesoscale eddy (Haida-2000a) in the eastern Gulf of Alaska (GOA) 4 times over a 20 mo period as it propagated westward away from the coast and into high-nitrate, low-chlorophyll waters. Phytoplankton species diversity in the eddy was higher in late summer/early autumn (September) than in spring (June) and it declined between the first and second years of evolution. Phytoplankton diversity within the eddy was greater than in the surrounding area in September (but not in June) in both the first and second years of evolution. Small cells dominated the phytoplankton assemblages throughout the study at all sites. The prevalence of coastal species in the eddy and its surroundings declined between the first and second years of eddy evolution. During the same period, the contribution of haptophytes and pelagophytes increased. Haida-2000a had a lower abundance of diatoms than its surroundings after one year of evolution, possibly due to the preferential export of silica from the eddy. Pigment and phytoplankton distributions indicated that edge sites differed from the center and outside, either due to the advective entrainment of surrounding waters into eddy circulation, or as a consequence of local upwelling at the eddy margins. The data suggest that eddies may respond differently than surrounding waters to external forcing, including storms and iron deposition events, thereby contributing to variability and large-scale patchiness of phytoplankton populations observed in the GOA.
\end{abstract}

KEY WORDS: Phytoplankton $\cdot$ Haida eddies $\cdot$ Pigments $\cdot$ Northeast Pacific $\cdot$ Gulf of Alaska Resale or republication not permitted without written consent of the publisher

\section{INTRODUCTION}

The Gulf of Alaska (GOA) is characterized by a cyclonic gyre (the Alaska Gyre), with seasonal coastal upwelling along the southeastern margin and downwelling to the north. A large region within the gyre possesses excess nutrients year round, a condition referred to as highnitrate, low-chlorophyll (HNLC) (Whitney \& Freeland 1999). The lower than expected chlorophyll concentrations are seasonally invariant (Boyd et al. 1995), although increases in surface chlorophyll a ( $\mathrm{chl}$ a) along the shelf break have been described using satellite ocean color, which permits higher-resolution observations in space and time (Brickley \& Thomas 2004). A major contribution to the variability in chl a comes from anticyclonic mesoscale eddies characterized by positive sea surface height anomalies of 5 to $30 \mathrm{~cm}$. Using satellite data, it has been estimated that anticyclonic eddies can account for $>50 \%$ of surface chl a within the $4 \mathrm{~cm}$ height contour, despite the fact that they represent only $\sim 10 \%$ of the surface area of pelagic waters (>500 $\mathrm{m}$ depth) in the GOA (Crawford et al. 2007). The large contribution to total phytoplankton biomass by eddies indicates that they play an important role in biogeochemical cycles within the GOA. Yet the phytoplankton assemblages accounting for these patterns in chl a are very poorly known. 
Mesoscale eddies, formed at several locations over the eastern Pacific margin, are named after the location in which they originate; those that recur annually are called the Haida, Sitka, and Yakutat eddies (Henson \& Thomas 2008).

Different taxonomic groups among the phytoplankton play unique biogeochemical roles that profoundly influence ecosystem fluxes (Verity \& Smetacek 1996), including export production and elemental cycling (Buesseler et al. 2007). For example, the evolution and radiation of diatoms has been observed to profoundly change the global marine silica cycle (Yool \& Tyrrell 2003, Falkowski et al. 2004), and to intimately link the carbon and silica cycles (Tréguer \& Pondaven 2000, Coale et al. 2004). Early studies suggested that phytoplankton diversity and species richness were low in the oceanic realm of the North Pacific (Beklemishev \& Nakonechnaya 1972), although this notion was refuted when small cells were taken into account. Not only was diversity found to be high, but small cells were seen to vary biochemically, and to include representatives of various siliceous and calcareous taxa (Booth et al. 1982, Taylor \& Waters 1982, Booth 1988). Occasionally 'blooms' of large diatoms (Clemons \& Miller 1984) or coccolithophores (Gower 1997, Lipsen et al. 2007) have been

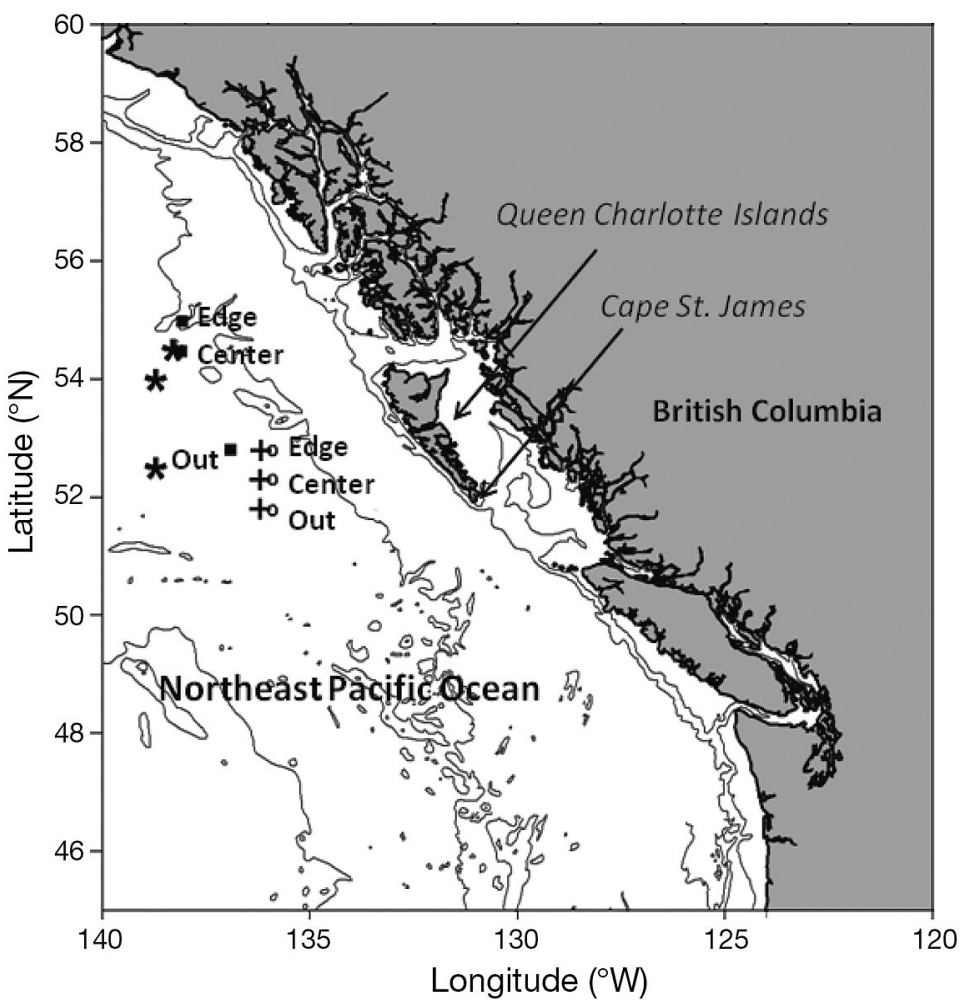

Fig. 1. Locations of sites sampled during 4 Haida eddy surveys. Different symbols correspond to locations of sampling for a given cruise. $\mathrm{O}$ : stations sampled in June 2000, +: September 2000, 口: June 2001, * : September 2001 observed, and episodes of high production have been inferred from high carbon and nitrogen fluxes to sediment traps at Ocean Station P (OSP, $50^{\circ} \mathrm{N}, 145^{\circ} \mathrm{W}$ ) (Wong et al. 1999). More typically, the phytoplankton populations are kept in check either by limitation of growth by low iron (in the case of the larger cells) or by grazing by microzooplankton (small cells) (Miller et al. 1991, Harrison 2002), the combination of iron limitation of growth of large phytoplankton and a tight coupling between growth of small cells and grazing of these small cells by microzooplankton (Miller et al. 1991) keeps the phytoplankton populations nearly constant year round and dominated by small cells (Harrison 2002).

The present study focuses on Haida eddies, a class of oceanic anticyclones formed off the southern tip of the Queen Charlotte Islands (Haida Gwaii) near Cape St. James (Fig. 1) (Crawford et al. 2002, Di Lorenzo et al. 2005). Haida eddies are named after the First Nation peoples that occupy the island group. These eddies are relatively large (150 to $300 \mathrm{~km}$ ) and long-lived (>1 yr; Crawford 2002). A ship-of-opportunity survey showed that coastal phytoplankton species were associated with an eddy early (age $<4 \mathrm{mo}$ ) in its evolution (Batten $\&$ Crawford 2005), and satellite imagery revealed a phytoplankton bloom ( $>10$-fold enrichment of chl a) at the center of an eddy formed in February 2000 (Crawford et al. 2005). Initially, Haida eddies remain fairly intact and separate from their surroundings, with limited horizontal exchange with their surroundings (Yelland \& Crawford 2005). However, during winter, when storm activity increases, they exhibit not only significant vertical mixing, but also greater horizontal exchange with surrounding waters (Mackas et al. 2005). In a sense, over the winter, the mixed layer of Haida eddies is 're-set' to local conditions. Thus, during the first year of evolution, Haida eddies may be thought to carry a coastal signature and undergo ecological succession, while in the second year of evolution any differences in phytoplankton assemblages compared to the surroundings would likely be due to eddy circulation and dynamics.

Haida eddies are excellent natural laboratories to study changes in planktonic communities in the GOA since they originate in coastal waters where phytoplankton growth is characteristically limited by nitrogen in the summer (Whitney et al. 1998, Whitney \& Freeland 1999), and then drift into HNLC waters where elements such as iron limit growth (Martin \& Fitzwater 1988). We tracked a Haida eddy called Haida-2000a between February 2000 and September 
2001, sampling its waters 4 times during that period. The objective of this study was to describe-by algal pigment analysis using light microscopy and chemotaxonomy - the evolution of phytoplankton species composition within Haida-2000a as it drifted away from the coast. We hypothesized that early in the eddy evolution the planktonic assemblage would be characterized by coastal species, while in subsequent years significant colonization by oceanic taxa would occur, making the species composition more similar to that of non-eddy waters. We further hypothesized that, subsequent to the natal year, algal assemblages would be influenced mainly by differences in nutrients and physical processes (for example, mixed-layer dynamics) between anticyclonic eddies and their surroundings.

\section{MATERIALS AND METHODS}

Cruises and sample collection. Individual Haida eddies are named according to the year of formation; in years where more than one eddy is spawned, they are named sequentially beginning with the suffix ' $a$ '. Haida-2000a was identified as a positive sea-surface height anomaly (SSHA) by radar altimetry (TOPEX/ Poseidon-ERS-2, provided through the Colorado Center for Astrodynamics Research). Samples for algal pigment analysis and species identification and enumeration were collected during 4 cruises aboard the CCGS 'J. P. Tully', one cruise each in June 2000, September 2000, June 2001, and September 2001. In each case, the 3 sites chosen for comparison were at the eddy center and edge, and outside the eddy (Fig. 1). The general location of Haida-2000a was informed by radar altimetry maps. Based on this information, the ship was deployed to the region of interest to perform a transect survey using conductivity-temperature-depth (CTD) casts to a depth of $1000 \mathrm{~m}$, with the purpose of determining the physical structure of the water column. The resulting contour plots were analyzed to determine, first, the location of the eddy center (region with flattened isopycnals and small near-surface currents as determined by a hull-mounted acoustic Doppler current profiler, ADCP), and second, the eddy edges (region with the most steeply sloping isopycnals and swiftest near-surface currents; see Yelland \& Crawford 2005).

Vertical CTD profiles were obtained along the transect using a Seabird 911plus CTD mounted to a 24-bottle rosette at sites within and outside of Haida2000a. The mixed-layer depth was calculated as the depth at which a 0.125 unit change in sigma-theta $\left(\sigma_{\theta}\right)$ was observed relative to the surface (Millero \& Poisson 1981). For phytoplankton identification and enumeration, seawater was carefully drawn into high-density polyethylene (HDPE, used in June 2000 only) or amber glass $250 \mathrm{ml}$ bottles. In order to reduce turbulence, which can damage cells that are sensitive to disturbance, water was drawn carefully through well used latex tubing. For the samples collected in June 2000, glass cover slips were added to the HDPE bottles in order to reduce the likelihood of diatom dissolution. Particulate organic carbon (POC) was determined in accordance with Verardo et al. (1990).

High-performance liquid chromatography (HPLC) pigment analysis. Seawater samples (1 1) were filtered onto $47 \mathrm{~mm} \mathrm{GF/F} \mathrm{filters} \mathrm{under} \mathrm{gentle} \mathrm{vacuum} \mathrm{pressure}$ (<100 mm Hg) and stored in liquid nitrogen pending analysis by high-performance liquid chromatography (HPLC), following protocols given in Wong \& Crawford (2006). Pigment concentrations were determined relative to standards and the identity of each was secured through co-elution with authentic pigments (Sigma Chemical Co. or DHI, Denmark). Because the method does not separate $\operatorname{chl} C_{1}$ and $C_{2}$, these were reported together as chl $c_{1}+C_{2}$. The pigments analyzed by HPLC included alloxanthin, $\beta$-carotene, $\operatorname{chl} a, \operatorname{chl} b$, chl $c_{1}+c_{2}$, chl $c_{3}$, diadinoxanthin, fucoxanthin, peridinin, prasinoxanthin, violaxanthin, zeaxanthin, 19'-butanoyloxyfucoxanthin (19'-but), and 19'-hexanoyloxyfucoxanthin (19'-hex). The detection limit for all pigments was $\sim 0.001 \mathrm{\mu g} \mathrm{l}^{-1}$; between-sample errors of 5 to $20 \%$ were obtained based on the analysis of 5 replicates using a subset of the samples $(n=60)$. Pigment concentrations were integrated to $50 \mathrm{~m}$, (generally close to the depth of the euphotic zone as determined by the $1 \%$ light level) by trapezoidal integration of observations from 6 depths within the euphotic zone. These depths were at $100,55,33,10,3$, and $1 \%$ of surface irradiance, as determined using a BioSpherical photosynthetically active radiation (PAR) sensor mounted to the CTD rosette frame. Chemotaxonomy makes use of characteristic accessory pigments to distinguish among algal classes, some pigments being unique to specific algal taxa (e.g. alloxanthin in cryptophytes), and others being encountered across several algal taxa (Jeffrey \& Wright 1997). Matrix factorization can be used to estimate the most likely composition of phytoplankton based on pigment ratios to chl a. We employed the CHEMTAX program (Mackey et al. 1996, 1997), run in MATLAB, to estimate the contributions of various algal classes to the total phytoplankton assemblage. The initial pigment-ratio matrix loaded into the CHEMTAX program was derived from averages of the ranges of pigment:chl a ratios observed for 10 phytoplankton classes, namely Bacillariophyceae, Chlorophyceae, Chrysophyceae, Cryptophyceae, Cyanophyceae, Dinophyceae, Euglenophyceae, Haptophyceae, Pelagophyceae, and Prasinophyceae (Mackey et al. 1997). The method is similar to that used by Suzuki et al. 
(2002). After finding the best fit to the data (100 iterations), CHEMTAX produced a final pigment-ratio matrix that was used to calculate the relative contribution to total chl a by each algal class.

Phytoplankton enumeration and species identification. As described above, samples for phytoplankton identification and enumeration were collected from 6 depths within the euphotic zone: 100, 55, 33, 10, 3, and $1 \%$ of surface irradiance. They were preserved in $0.5 \%$ hexamethylenetetramine-buffered formalin or $1 \%$ Lugol's iodine for counting under the inverted microscope (Utermöhl 1958). To achieve statistical power, at least 400 cells per sample were counted. Cells were counted at $400 \times$ magnification, with additional counts performed at $100 \times$ magnification to incorporate rare cells appearing in the larger area of observation. On average, from 20 to 40 fields were examined per sample.

For each taxon enumerated, the cell dimensions were measured under the microscope using an ocular micrometer. The geometries were described based on simple shapes (e.g. cones, cylinders, boxes) or combinations of these (Sun \& Liu 2003). The concentration of carbon per cell was calculated in accordance with Menden-Deuer \& Lessard (2000) and Strathmann (1967). In these calculations large diatoms, because of their vacuole, are assumed to possess less carbon per cell than other, similar-sized organisms.

In order to compare phytoplankton species composition and contribution to total cell carbon above the mixed layer as opposed to below it, the abundance and carbon content associated with each taxon were each averaged among samples collected either above or below the mixed layer. Error bars, when presented, reflect \pm 1 SD from the mean. For cell abundance, this was generally between 5 and $10 \%$ and for cell carbon between 15 and $20 \%$.

Ecological indices. The Shannon-Wiener index $\left(H^{\prime}\right)$ was used to evaluate diversity. A 2-way analysis of variance (with Tukey multiple-comparisons post hoc test procedure) was used to compare diversity values for different months (namely June versus September) and different years (namely 2000 versus 2001). Dominancediversity curves (also referred to as rank abundance curves) were plotted for each of the sites to visually represent species richness and evenness. The use of dominance-diversity curves avoids the problem of combining these 2 parameters into one coefficient (Jeffrey \& Hallegraeff 1987). In this analysis, the flatter the slope of the semi-log curve of cell abundance versus total number of species (i.e. richness), the greater the evenness; the steeper the slope, the lower the evenness. To estimate evenness, we computed the slope of the linear portion of the log-log plots of the ranked abundance data and compared them across month (June versus Septem- ber) and year (2000 versus 2001) using a 2-way ANOVA with a Tukey multiple-comparisons post hoc test procedure. This approach down-weights the rarer taxa.

To assess similarity/dissimilarity among sites, a cluster analysis was performed on phytoplankton abundance data using MVSP v3.13. An agglomerative hierarchical algorithm was employed (using the unweighted pair group method with arithmetic mean, [UPGMA], or average linkage method) grouped according to the Bray-Curtis distance (Bray \& Curtis 1957), where smaller Bray-Curtis distance indicates greater similarity.

\section{RESULTS}

\section{Evolution of Haida-2000a}

The evolution of the Haida-2000a eddy has been described elsewhere (Miller et al. 2005, Peterson et al. 2005), but we highlight important features here to provide a context for the phytoplankton observations. Haida-2000a was formed in February 2000, and drifted due west between February and June 2000 to a position directly over Bowie Seamount, a shallow ( 35 m below the sea surface) seamount in the eastern GOA $\left(53.3^{\circ} \mathrm{N}, 135.7^{\circ} \mathrm{W}\right)$, ca. $180 \mathrm{~km}$ west of the Queen Charlotte Islands. Due to its interaction with the seamount, Haida-2000a remained nearly stationary until September 2000 (Fig. 1). Between September 2000 and June 2001 the eddy drifted west-northwest into the Alaska Gyre, where it coalesced with a second, younger eddy (Haida-2001a) between June and August 2001. By September 2001 Haida-2000a was situated in the HNLC waters of the GOA. Over the 20 mo period the eddy energy declined, as indicated by a decrease in sea surface height anomaly and a relaxation of isopycnal depression. Nutrients (nitrate, phosphate and silicic acid) were nearly depleted between February and June 2000, following a spring phytoplankton bloom, and were partially replenished over the summer to autumn period, likely through the relaxation of isopycnal depression. For a full description of nutrient dynamics observed during the evolution of the Haida-2000a eddy see Peterson et al. (2005).

Winter convective mixing injected nutrients into the near-surface waters of the eddy and its surroundings; however, nutrient drawdown was weaker in Year 2 of evolution than in Year 1, presumably due to declining levels of iron (Johnson et al. 2005). Notably, a storm event during September 2001 resulted in a vertically homogeneous distribution of chl a (down to 30-35 m) at the eddy center (Crawford et al. 2005). At this time the vertical stability as estimated by the Brunt-Väisälä frequency ( $\mathrm{N}$, in cycles per second, or $\mathrm{Hz}$ ) was 5 times higher than 
in September 2000 at both the eddy center and in surrounding waters (0.004 compared to $0.021 \mathrm{~Hz}$ at both the center and outside). However, $\mathrm{N}$ values at the edge were similar for all cruises after June 2000 (0.014, 0.012, $0.019 \mathrm{~Hz}$ for September 2000, June 2001, and September 2001, respectively; data not shown).

\section{Algal pigments within and outside of a Haida eddy}

Algal pigment distributions varied over time, as well as among sites (Fig. 2). Vertically integrated pigment concentrations were higher in Year 1 (2000) of the study than in Year 2 (2001), with the exception of chl $C_{1}+C_{2}$, chl $C_{3}$, and peridinin, which were higher in Year 2. Some pigments were observed mainly in either June or September, suggesting there was seasonality in their distributions; an example is alloxanthin, which was observed only in June 2000 when the eddy was closest to the coast, and not at other times. Violaxanthin (integrated values not shown) was found only in September, and was more abundant in September 2000 (all sites, ca. $0.25 \mu \mathrm{g} \mathrm{l}^{-1}$ ) than in September 2001 (eddy edge only, $0.15 \mu \mathrm{g} \mathrm{l}^{-1}$; data not shown). Other
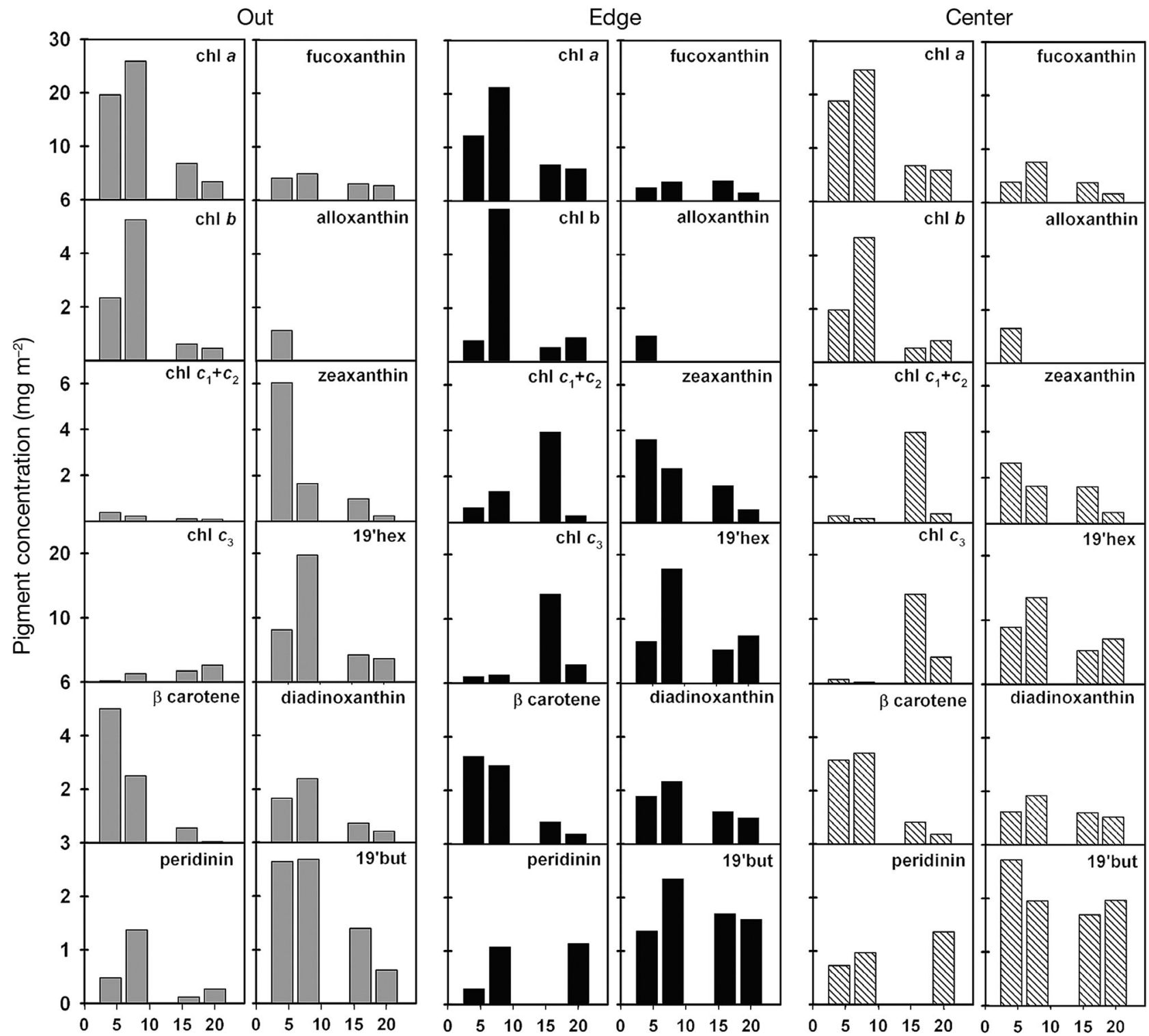

Months since eddy formation (February 2000)

Fig. 2. Depth-integrated pigment concentrations from sites outside of Haida-2000a (Out), at the eddy edge (Edge), and at the eddy center (Center), determined 4 times over a 20 mo period. Prasinoxanthin and violaxanthin are not shown since concentrations were low throughout the study. Chlorophylls $c_{1}$ and $c_{2}$ are included together since the two co-elute during analysis 
pigments were more prominent in Year 1 than in Year 2, and vice versa. For example, chl $b$ and diadinoxanthin declined dramatically between Year 1 and Year 2, whereas chl $C_{1}+C_{2}$ and chl $C_{3}$ were observed mainly in Year 2. Certain pigments were observed both in the waters outside of the eddy as well as within the eddy (both center and edge) when Haida-2000a was situated close to the coast, but declined in the outside waters as the eddy drifted westward. These pigments included zeaxanthin, diadinoxanthin, and $19^{\prime}=$ but. The fact that they declined less dramatically within the eddy suggests that the phytoplankton assemblages retained elements of their coastal character over time. Perhaps the most notable difference between eddy and non-eddy sites was the presence of enhanced chl $C_{1}+C_{2}$, chl $C_{3}$, and peridinin within the Haida-2000a eddy (Fig. 2).

The vertical profiles varied with pigment type, site with respect to the eddy, and time (Fig. 3). When Haida-2000a was 4 mo old (June 2000), a subsurface chl a maximum appeared at the eddy center $(0.58 \mu \mathrm{g}$ $\mathrm{l}^{-1}$ at ca. $\left.37 \mathrm{~m}\right)$; this was mirrored by the vertical distribution of fucoxanthin, peridinin, 19'-hex, and 19'-but. Subsurface pigment maxima were not commonly observed at any of the sites after June 2000. Exceptions included chl $b$ (eddy center and outside station, September 2000), chl $c_{3}$ (center, June and September 2001), and fucoxanthin (center, September 2000) which exhibited subsurface maxima. More commonly, pigment maxima were found within the mixed layer (Fig. 3).

\section{Phytoplankton species composition}

\section{Pigment analysis}

According to pigment analysis and CHEMTAX matrix factorization, the phytoplankton assemblages in 2000 differed from those in 2001 (Fig. 4). Between Year 1 and Year 2 there was a decline in diatoms, chlorophytes, and Synechococcus spp., and an increase in haptophytes and pelagophytes. In Year 2 haptophytes were more prominent in the eddy sites than in the outside reference sites. Cryptophytes were observed mainly in June, while dinoflagellates were observed mainly in September of both years (at all sites). Contributions to total chl a by chlorophytes, prasinophytes, chrysophytes (data not shown), and euglenophytes were small throughout the study. Interestingly, in June 2000, haptophytes were common in surface waters of the eddy center, but not at the eddy edge or in surrounding waters.

The chemotaxonomic composition above and below the mixed layer were similar at all sites. However, there was a greater contribution to total chl a by prasinophytes in waters below the mixed layer, and euglenophytes were more prevalent above the mixed layer.

Microscopy and phytoplankton carbon estimates

Between June 2000 and June 2001 total cell abundances (cells $\mathrm{l}^{-1}$ ) increased over time both above and below the mixed layer (Fig. 5). Between June 2001 and September 2001, cell abundance did not increase except in the mixed layer at the center of Haida-2000a, and actually decreased at the outside reference site. Changes in carbon attributed to phytoplankton $\left(\mathrm{C}_{\text {phtyo }}\right)$ showed a similar trend at the outside reference sites, but not at the eddy center or edge sites. Instead, $\mathrm{C}_{\text {phyto }}$ values were higher in September of both years in the mixed layer at the eddy center and edge sites. Below the mixed layer, $\mathrm{C}_{\text {phtyo }}$ increased between June and September 2001 at the outside reference site, while remaining approximately the same for this period at both eddy sites.

The proportion of $\mathrm{C}_{\text {phyto }}$ to total POC increased over time, particularly at the outside reference waters where the calculated $\mathrm{C}_{\text {phyto }}$ accounted for nearly all POC. The values reported for the September 2001 observations might reflect an overestimation due to the low cellular content of diatoms (especially Thalassiosira delicatula), which was not accounted for in the carbon calculations. Few microzooplankton cells were observed at the outside reference site in either June or September 2001 (data not shown). While, within the mixed layer, $\mathrm{C}_{\text {phyto }}$ made a greater contribution to total POC at the outside references sites as compared to the eddy center and edge, below the mixed layer algal contributions to POC were smallest at the outside reference sites (Fig. 5).

Nanoflagellates dominated the phytoplankton assemblage in terms of numbers, while diatoms or dinoflagellates dominated in terms of carbon (Fig. 6). No netplankton (20 to $200 \mu \mathrm{m}$ diam.) were dominant at any station during the study, with the exception of the outside reference site in September 2001 where the diatom Thalassiosira delicatula represented $\sim 78 \%$ of total cell carbon and $\sim 26 \%$ of total cell abundance. In June 2001, at the edge and center of Haida-2000a, diatoms represented a $\sim 80 \%$ of total cell carbon (Fig. 6). The diatoms present in the assemblage consisted mainly of pennates, including Fossula arctica, Fragilariopsis kerguelensis, Pseudo-nitzschia spp., Nitzschia cylindriformis $(<10 \mu \mathrm{m}$ diam.), Nitzschia spp., Navicula spp., and Tropidoneis lepidoptera.

Phytoplankton species composition was not examined in February 2000, when Haida-2000 was formed; 
however, surface samples from the eddy center and a non-eddy site were collected during a cruise in February 2001 (data not shown). Although the total chl a concentration in the mixed layer at the eddy center was similar to that of the outside reference site (data not shown), the taxonomic diversity of phytoplankton within the eddy was greater than that of the outside reference site in February 2001 (Table 1). The proportion of dinoflagellates was twice as large within the eddy as in non-eddy waters, while diatoms (mainly chain-forming pennates such as Fragilaria and Navicula) were proportionally more abundant outside the eddy. Fewer prasinophyte taxa were observed at the non-eddy site; within the eddy this taxon was represented by Pterosperma spp. and Pyraminomas sp. At both sites the dominant phytoplankton were unidentified nanoflagellates.

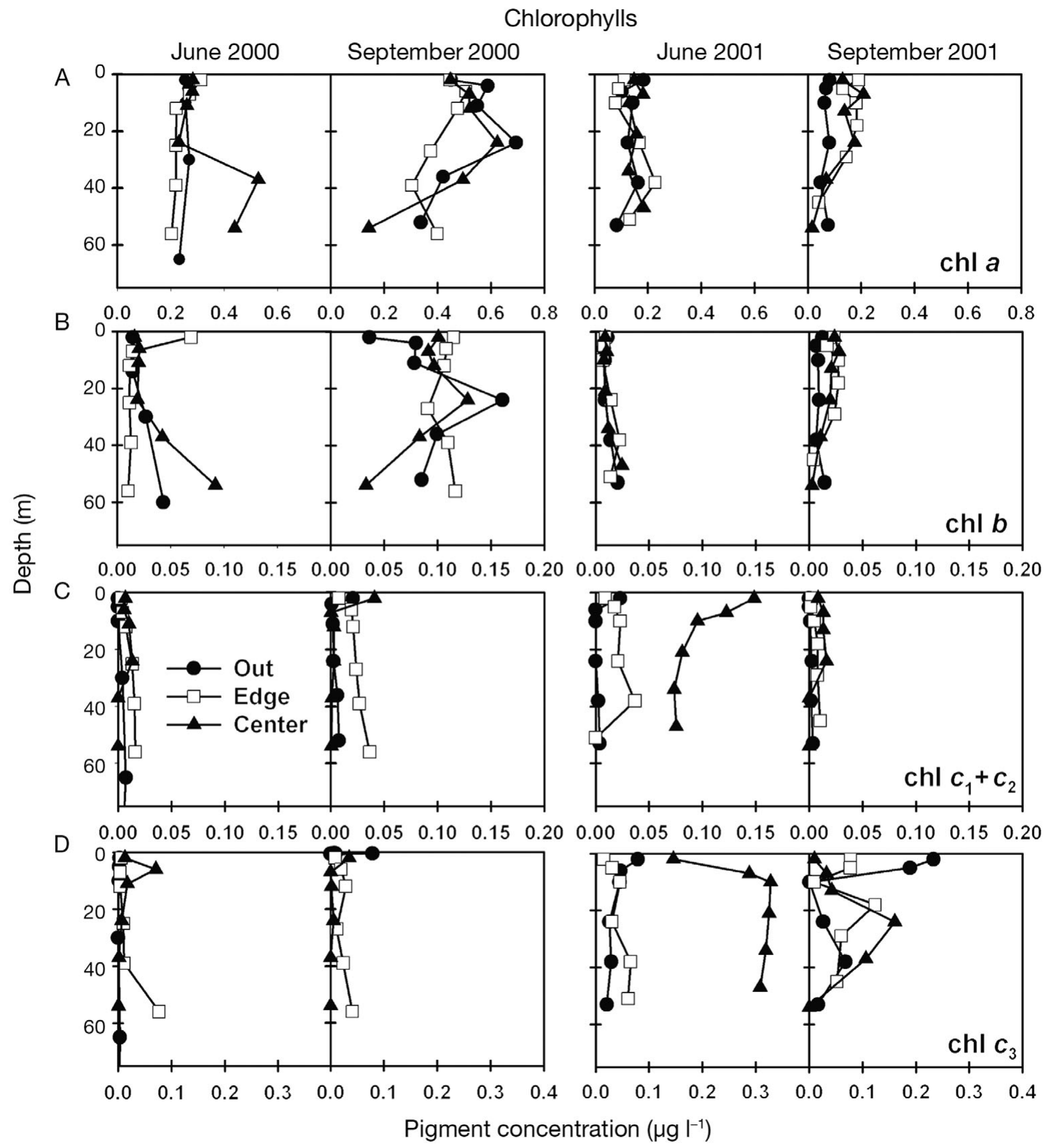

Fig. 3 (Above and following 2 pages). Depth profiles of algal pigments at the outside, edge, and eddy center sites during June and September 2000 and 2001. Chlorophyll pigments: (A) chl $a_{1}$ (B) chl $b_{1}$ (C) chl $c_{1}+c_{2}$, and (D) chl $c_{3}$; Xanthophyll pigments: (E) fucoxanthin, (F) alloxanthin, (G) zeaxanthin, (H) diadinoxanthin, (I) violaxanthin, (J) 19'-hexanoyloxyfucoxanthin, and (K) 19'-butanoyloxyfucoxanthin; Acid pigments: (L) $\beta$-carotene, (M) peridinin 


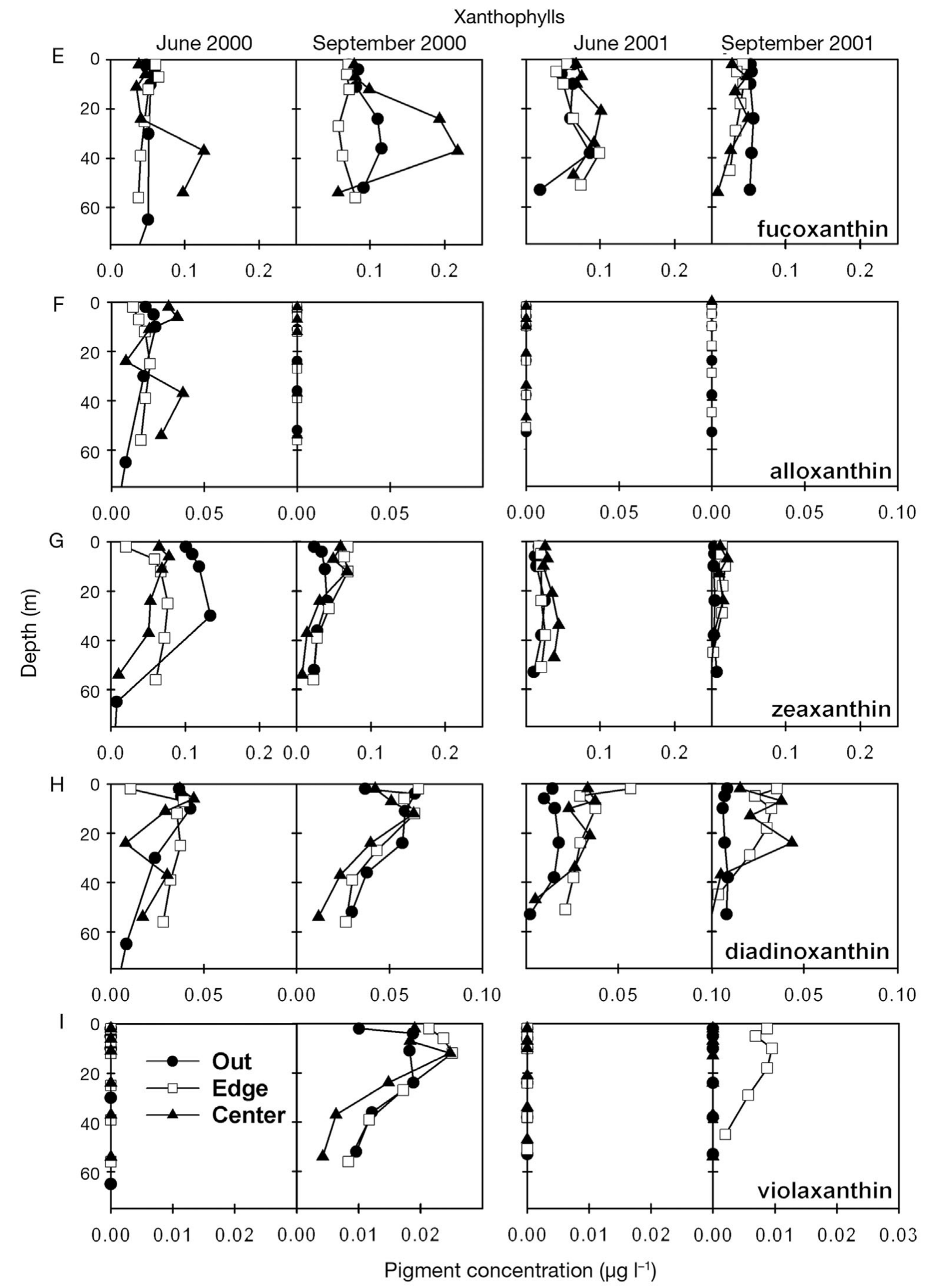

Fig. 3 (continued) 

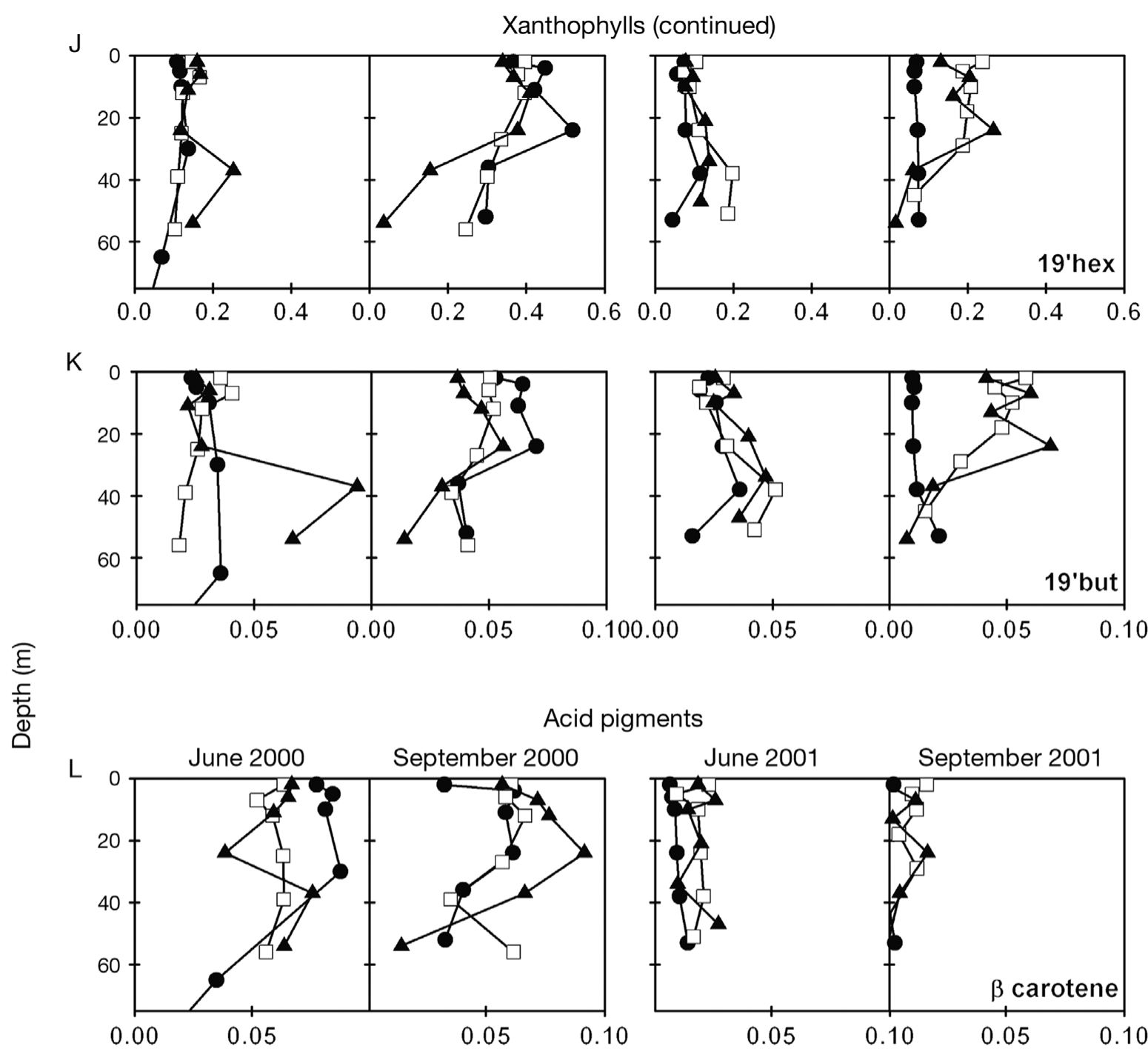

हิ
홍
อ
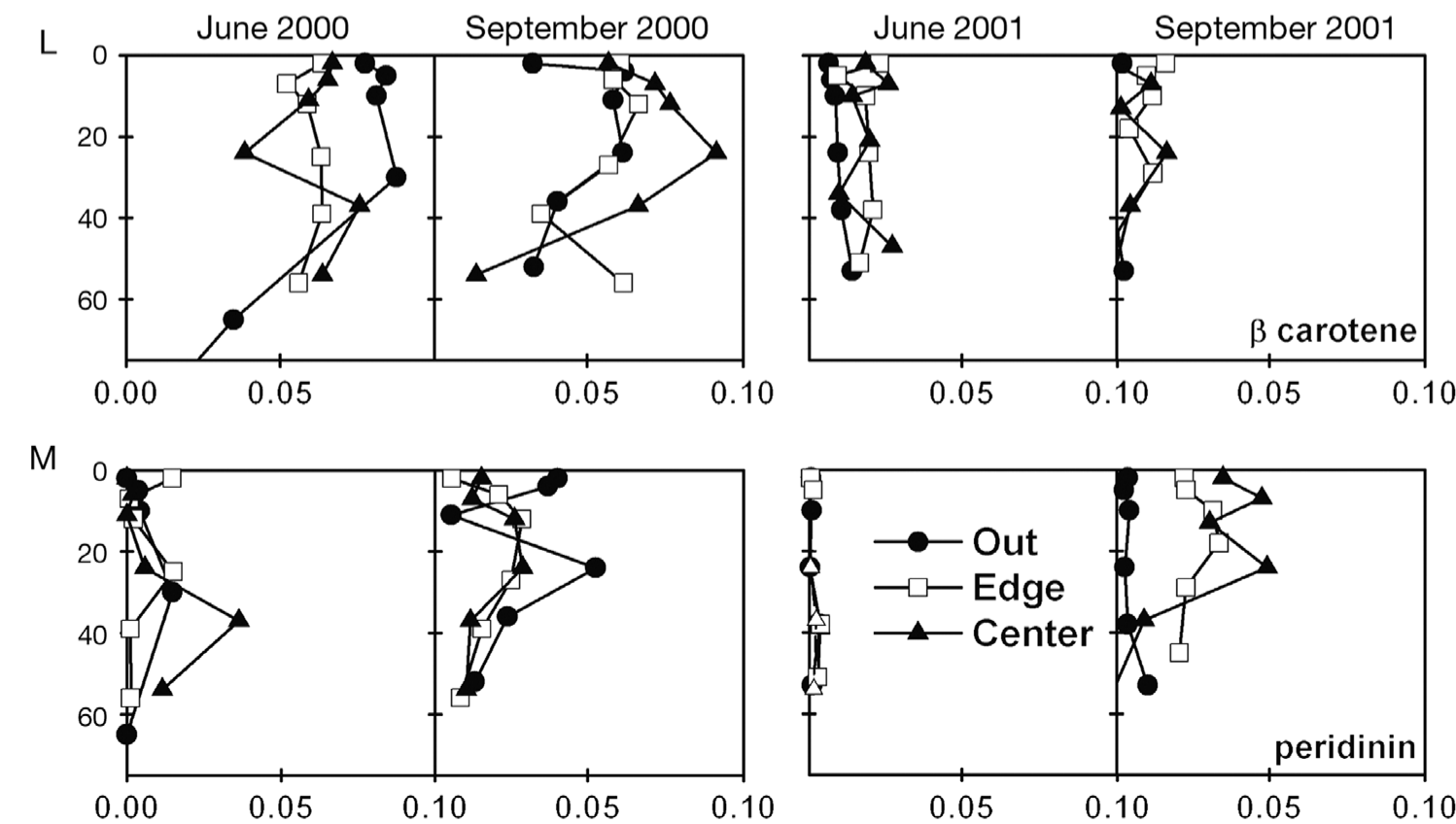

Pigment concentration $\left(\mu \mathrm{g} \mathrm{I}^{-1}\right)$

Fig. 3 (continued)

Without corresponding HPLC measurements, however, it is difficult to assign taxonomic designations to individuals falling within this group.

The shapes of the dominance-diversity curves were similar among the sites, with differences in steepness apparent between June and September cruises (Fig. 7). Diversity was significantly higher in 2000 than in 2001, both in eddy and non-eddy waters (Table 1; $p=0.024)$. In contrast, there was no significant difference in evenness between 2000 and 2001 (Fig. 7, 


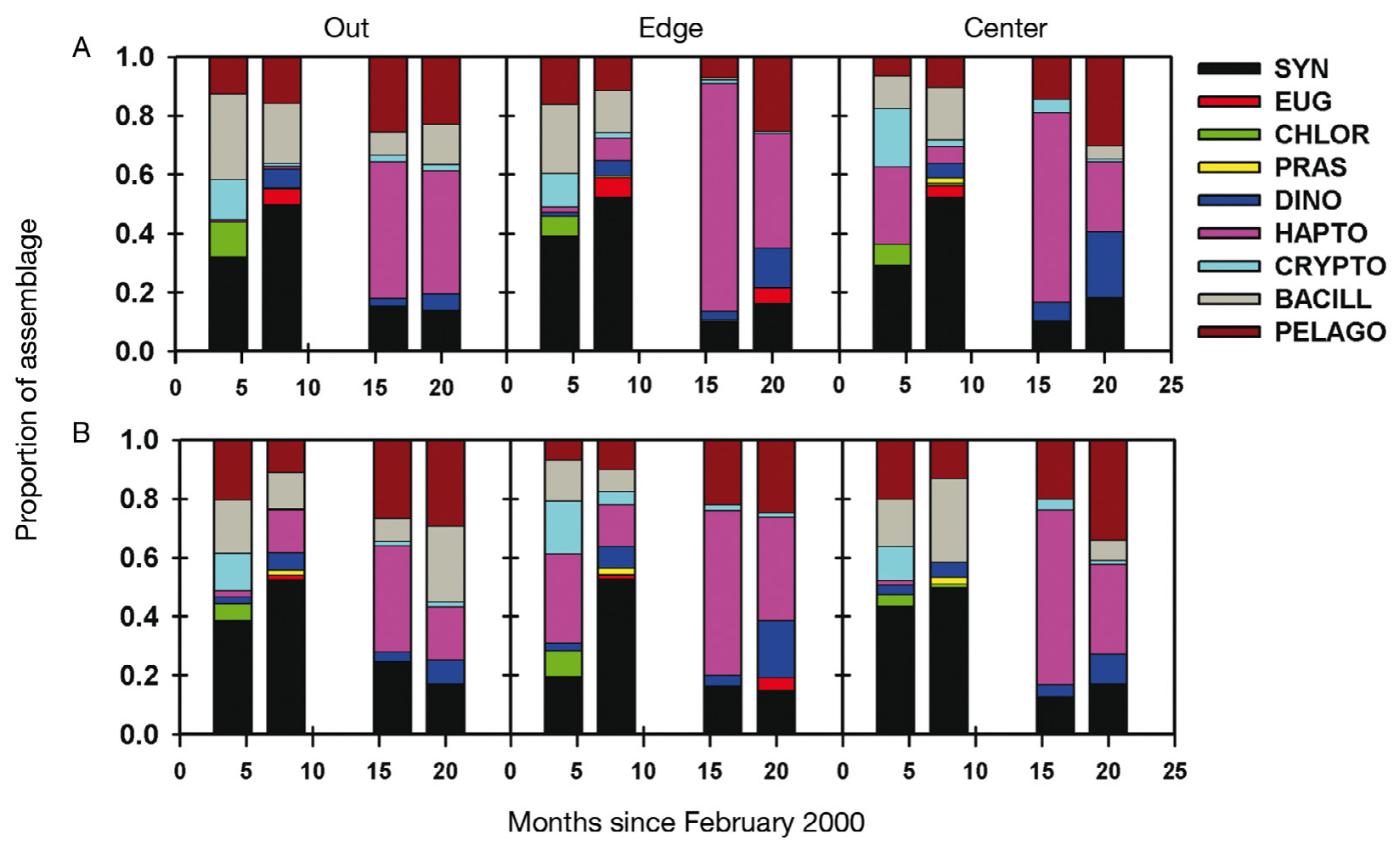

Fig. 4. Proportion of total phytoplankton accounted for by 9 algal classes: Cyanophyceae (Synechococcus-type) = SYN, Euglenophyceae $=$ EUG, Prasinophyceae $=$ PRAS, Cryptophyceae $=$ CRYPTO, Dinophyceae $=$ DINO, Bacillariophyceae $=$ BACILL, Haptophyceae $=$ HAPTO, Chlorophyceae $=$ CHLOR, and Pelagophyceae $=$ PELAGO, in water $(\mathrm{A})$ above and $(\mathrm{B})$ below the mixed layer at outside, edge and center sites during the 4 cruises. Data derived from CHEMTAX analysis

Table $1 ; \mathrm{p}=0.23)$. It is interesting to note that the phytoplankton assemblages in the eddy were more diverse than those outside the eddy in September when overall diversity levels were highest, but not in June. Intriguingly, a seasonal difference was noted in both metrics in the eddy but not in the outside reference waters, with higher values observed in September than in June (Table 1; $\mathrm{p}<0.001$ for each test, 1-way ANOVA with a Tukey post hoc multiple-comparisons procedure). In the eddy, the slopes of the dominancediversity curves (indicating the greatest evenness) were significantly less steep in September 2000 compared to the other cruises (June 2000, June 2001, or September 2001) (Fig. 7). No other significant differences in the slopes were observed as the eddy evolved.

A comparison between the dominance-diversity slopes calculated based on carbon units (log carbon vs. species rank) versus abundance data (log abundance vs. species rank) yielded similar results for 3 out of the 4 cruises (September 2001 being the exception). In September 2001, the average slope calculated from estimated carbon biomass was -2.1 , whereas it was -1.6 as calculated from species abundance (data not shown). This discrepancy suggests that, in the Septem- ber 2001 samples, there may have been a number of different taxa of similar size. This is consistent with previous observations (Booth et al. 1982).

Occasionally, the freshwater centric diatom Aulacoseira granulata was observed, indicating an influence from rivers along the coastal margin, either through entrainment into near-surface, clockwise circulation or through resuspension of material at the bottom of Hecate Strait during eddy formation. These diatoms were observed in June 2000 and in June 2001 at the eddy edge, center, and in surrounding waters to the south of the eddy that were influenced by clockwise eddy circulation. Other indications that the eddy edge sites differed from the center or outside included the presence of euglenophytes only at the eddy edge in September 2001, and (in September 2000) greater diatom species richness at the eddy edge (30 species) than in surrounding waters (6 species). A cluster analysis that grouped sites according to species composition indicated that the edge was often an outlier to the center and outside. This was evident particularly above the mixed layer in September of both years and below the mixed layer in June of both years (Fig. 8). 
A

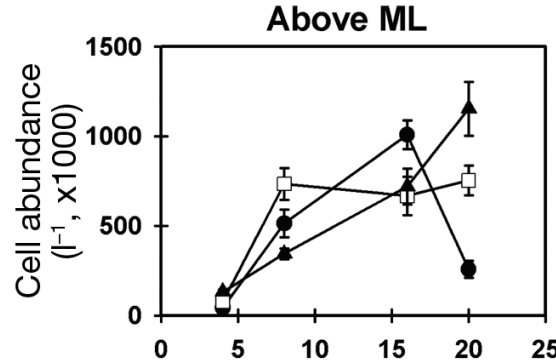

B

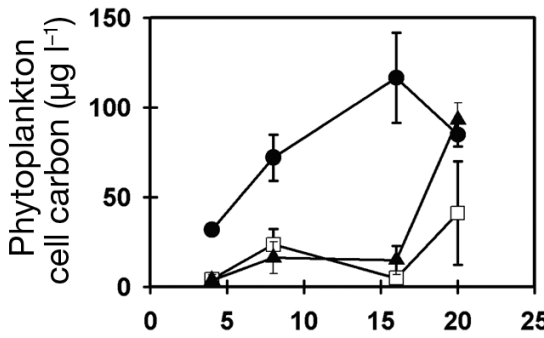

250
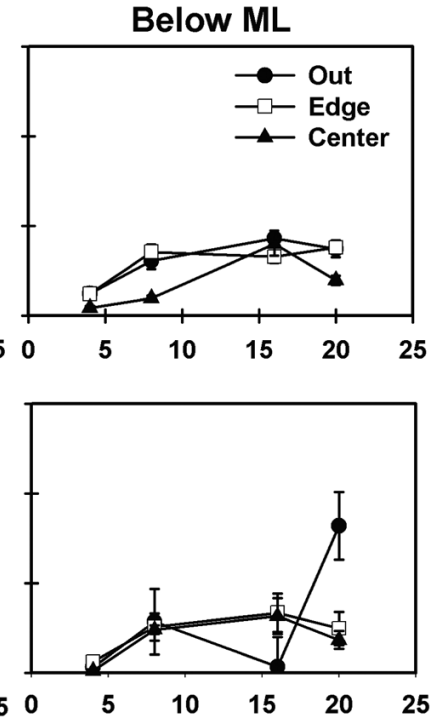

C

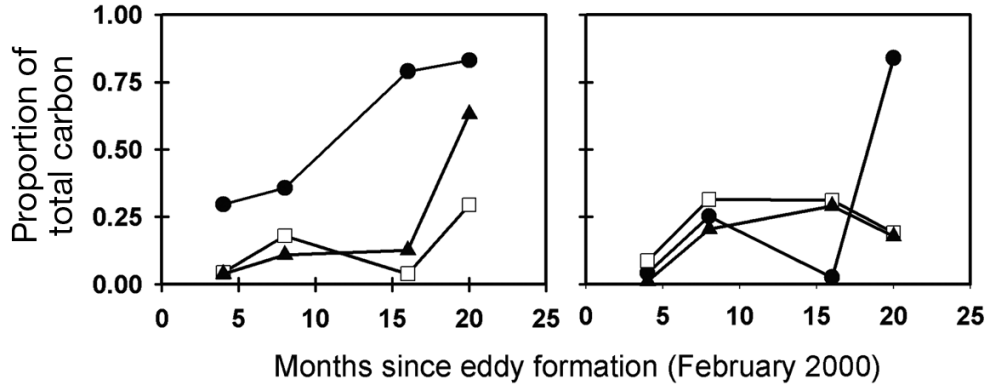

Fig. 5. (A) Total phytoplankton cell abundance (excluding Synechococcus spp.) above and below the mixed layer (ML) for outside, edge, and eddy center sites over the 20 mo study period; (B) total cell carbon calculated from cell dimensions at the same sites; $(\mathrm{C})$ contribution to total particulate organic carbon (POC) by estimated algal carbon

\section{DISCUSSION}

\section{General trends}

Mesoscale eddies are often associated with distinct algal flora (Fryxell et al. 1985, Gould \& Fryxell 1988, Rodriguez et al. 2003). Gould \& Fryxell (1988) showed that the patterns of ecological succession and the evolution of phytoplankton community composition within a warmcore ring occurred at different time scales as compared to surrounding waters, in their case the Sargasso Sea. Similarly, Rodriguez et al. (2003) found that SWODDIES (slope water oceanic eddies) in the Bay of Biscay - in contrast to waters outside these eddies - essentially trap waters from the continental slope and allow diatoms to flourish at the center. The processes accounting for differences in phytoplankton assemblages between eddies and their surroundings range from enhanced mixing in the short term (Hitchcock et al. 1987) and at seasonal scales (Hitchcock et al. 1985) to different mechanisms of nutrient supply to the mixed layer (McGillicuddy \&
Robinson 1997). The latter condition can arise due to isopycnal rebound that accompanies the frictional decay of anticyclonic mesoscale eddies (Fukumori 1992, Crawford et al. 2007). This mechanism injects nutrients into the waters above, and may explain the enhanced biological production often observed in anticyclonic (or downwelling) eddies (Hansen et al. 2010). The process is illustrated schematically in Fig. 9, along with other physical features of importance to primary productivity and species distribution within Haida eddies. For example, the entrainment of both offshore and nearshore waters into eddy circulation can influence the phytoplankton assemblages in the nearsurface waters, while the coalescence of eddies can influence the biogeochemical characteristics of aging eddies that contribute to shaping the phytoplankton assemblages.

By June 2000, nutrients were already low in Haida-2000a, following a spring phytoplankton bloom observed by satellite imagery. Likely by the mechanism of frictional decay and isopycnal rebound described above and shown schematically in Fig. 9, a replenishment of nutrients (detected by an increase in silicic acid) occurred within the eddy between June and September 2000 (Peterson et al. 2005). Coincident with the input of nutrients, phytoplankton diversity was maximal in September 2000, both within and outside of the Haida eddies. By September 2000, nitrate concentrations were low to undetectable outside of the eddy. Large diatoms showed an increased abundance at the eddy center and edge in early autumn (September) as compared to late spring (June); in contrast, dinoflagellates were more prevalent than diatoms in outside waters over the same period. Since dinoflagellates have the ability to migrate vertically to acquire nutrients (Dortch \& Maske 1982, Eppley et al. 1984), the low concentrations of nitrate may have made them more competitive with diatoms.

Large cells (>10 $\mu \mathrm{m}$ diam.) were surprisingly numerous in September 2001 when the eddy was in HNLC waters. This was the case both at the eddy center and in the surrounding waters (but not at the edge), possibly reflecting the strong vertical mixing associated with a storm event prior to and during our sampling. In September 2001, the phytoplankton assemblage within the eddy had a greater proportion of dinoflagellates, while the outside reference site had a large proportion of diatoms, dominated by Thalassiosira delicatula. These observations, together with the slower 

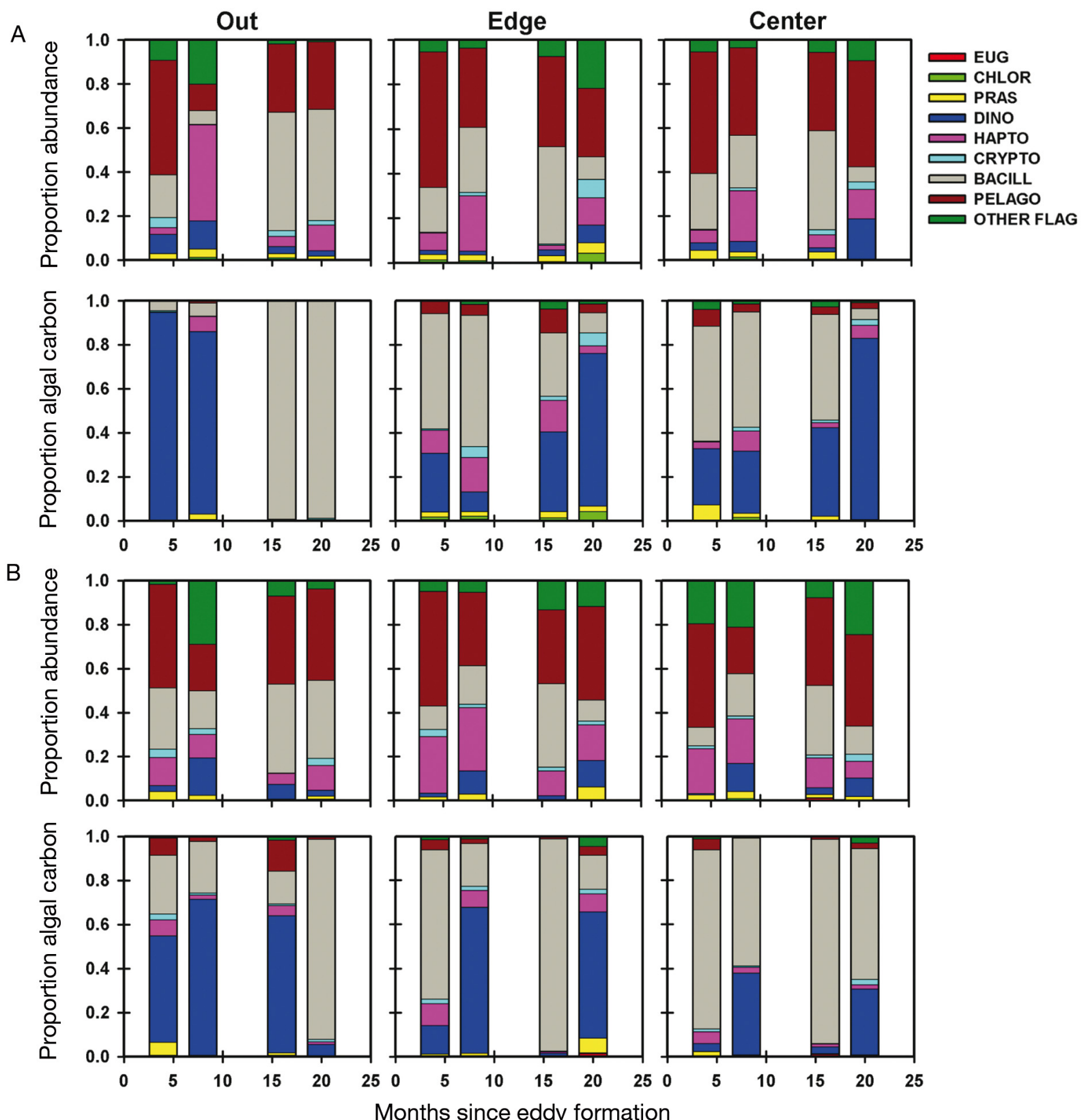

Fig. 6. Proportion of total cell abundance or cell carbon, determined by light microscopy, at outside, edge, and eddy center sites at depths (A) above and (B) below the mixed layer. Categories include euglenophytes (EUG), prasinophytes (PRAS), cryptophytes (CRYPTO), dinoflagellates (DINO), diatoms (Bacillariophyceae = BACILL), haptophytes (HAPTO), chlorophytes (CHLOR), pelagophytes (PELAGO) and miscellaneous nanoflagellates (OTHER FLAG)

decreases over time in some algal pigments (e.g. zeaxanthin, diadinoxanthin, and 19'-but) noted within the eddy as compared to the outside reference sites suggest that the phytoplankton assemblage within Haida eddies can remain quite distinct from the surroundings. This is in agreement with findings by Batten \& Crawford (2005) based on data collected by a continuous plankton recorder (CPR). Their data - which covered a much broader spatial extent than the present study - indicated that during early evolution (eddy age $<1 \mathrm{yr}$ ), distinct planktonic assemblages are associated with Haida and Sitka eddies. Our observations support the idea that the distinct assemblages are maintained over a long period. It is possible that the assemblages evolve independently within the eddy over the growing season, since differences in diversity metrics between the eddy and non-eddy waters were observed only in late summer and early autumn. The 
Table 1. Shannon-Wiener diversity index $\left(H^{\prime}\right)$, evenness, and slope with associated $\mathrm{R}^{2}$ values for the dominance-diversity curves for outside reference, eddy edge, and eddy center sites during cruises in June 2000, September 2000, February 2001, June 2001, and September 2001. The slopes were calculated from the linear portion of the log-log abundance versus rank curves. Values calculated for depths below the mixed layer are shown in brackets. Only surface values are reported for the February samples

\begin{tabular}{|c|c|c|c|c|c|}
\hline Cruise & Site & Diversity $\left(H^{\prime}\right)$ & Evenness & Slope & $\mathrm{R}^{2}$ \\
\hline \multirow[t]{3}{*}{ June 2000} & Outside & $2.26(2.08)$ & $0.54(0.59)$ & $-1.16(-2.10)$ & $0.95(0.83)$ \\
\hline & Edge & $1.74(1.82)$ & $0.47(0.47)$ & $-1.80(-2.10)$ & $0.74(0.88)$ \\
\hline & Center & $1.73(1.58)$ & $0.50(0.46)$ & $-1.82(-2.04)$ & $0.86(0.90)$ \\
\hline \multirow[t]{3}{*}{ September 2000} & Outside & $2.54(2.22)$ & $0.65(0.54)$ & $-1.27(-1.02)$ & $0.97(0.91)$ \\
\hline & Edge & $2.46(2.69)$ & $0.60(0.64)$ & $-1.68(-1.42)$ & $0.90(0.90)$ \\
\hline & Center & $3.46(3.29)$ & $0.62(0.78)$ & $-1.64(-1.01)$ & $0.75(0.97)$ \\
\hline \multirow[t]{2}{*}{ February 2001} & Outside & 2.00 & 0.60 & -1.71 & 0.95 \\
\hline & Center & 2.10 & 0.52 & -1.34 & 0.97 \\
\hline \multirow[t]{3}{*}{ June 2001} & Outside & $1.53(1.64)$ & $0.45(0.48)$ & $-1.45(-1.53)$ & $0.89(0.90)$ \\
\hline & Edge & $1.75(1.92)$ & $0.50(0.56)$ & $-1.96(-2.35)$ & $0.90(0.80)$ \\
\hline & Center & $1.65(1.88)$ & $0.48(0.50)$ & $-2.29(-1.71)$ & $0.78(0.89)$ \\
\hline \multirow[t]{3}{*}{ September 2001} & Outside & $1.85(2.25)$ & $0.52(0.57)$ & $-1.50(-2.04)$ & $0.88(0.90)$ \\
\hline & Edge & $2.63(2.29)$ & $0.63(0.61)$ & $-1.24(-2.07)$ & $0.96(0.85)$ \\
\hline & Center & $2.45(2.26)$ & $0.62(0.61)$ & $-1.25(-1.25)$ & $0.95(0.96)$ \\
\hline
\end{tabular}

CPR data suggest that, although there is variability among plankton assemblages outside of eddies, the differences between eddies and their surroundings are larger than among sites outside the eddies. Previous studies have suggested that spatial variability in phytoplankton distributions (Varela \& Harrison 1999) and rate processes (Pena \& Varela 2007) in the subarctic northeast Pacific largely follow broad environmental gradients, with the exception of areas associated with transition zones, which are characterized by steeper gradients (Ribalet et al. 2010).

The prevalence of dinoflagellates at the eddy center in September 2001 suggests that, perhaps in contrast to observations from other anticyclonic eddies where diatoms often become concentrated near the center (Hitchcock et al. 1985, Rodriguez et al. 2003), Haida eddies may develop a deficit in diatoms over time. This could arise from the preferential export of silica described for Haida eddies (Whitney et al. 2005) and eddies of the subtropical North Pacific Ocean (BenitezNelson et al. 2007), which would potentially reduce the standing stocks of siliceous taxa within Haida eddies. Interestingly, the silicic-acid:nitrate ratios (both within the mixed layer and the supply ratios) were lower within the eddy than in surrounding waters (Peterson et al. 2005), meaning that the prevalence of dinoflagellates over diatoms may have been a reflection of the different supply ratios of nutrients injected into the mixed layer due to frictional decay (Fukumori 1992).

It is not possible to directly compare the proportional contribution of the various taxa as estimated by chemotaxonomy and microscopy because data on the carbon:chl a ratios are required, and these ratios can vary under different light and nutrient regimes (Geider 1987). However, there was generally good agreement between the two methods, except that, in Year 2, the contribution by diatoms and dinoflagellates was either overestimated by microscopy or underestimated by CHEMTAX. This phenomenon could have arisen due to chlorosis in the larger phytoplankton induced by nutrient limitation, including low iron (Greene et al. 1992), or due to errors in classifying some of the smaller dinoflagellates as autotrophs rather than heterotrophs. Further, because CHEMTAX relies on the initial pigment ratio matrix to determine the relative contributions of various algal taxa to total chl $a$, significant errors could have been introduced by variations in pigment:chl a ratios.

Two pigments noted within Haida-2000a phytoplankton in June 2001, but negligible in outside waters were chl $C_{1}+C_{2}$ and $\mathrm{chl} C_{3}$. Chl $C_{1}+C_{2}$ are present in a number of algal taxa, and are therefore by themselves not diagnostic of particular classes associated with Haida-2000a in late spring 2001. Chl $C_{1}+C_{2}$ are found in Emiliania huxleyi, diatoms, raphidophytes, chrysophytes, dinoflagellates, and cryptophytes (Jeffrey \& Vesk 2005). However, chl $c_{3}$, while sometimes associated with diatoms and with some dinoflagellates, e.g. Gymnodinium mikimotoi (Suzuki \& Ishimaru 1992), is most often associated with the Pelagophyceae (Vesk \& Jeffrey 1987), a class closely related to chrysophytes (Andersen et al. 1993). We interpret this as an indication that pelagophytes were significantly more abundant in Haida-2000a than in outside waters. 


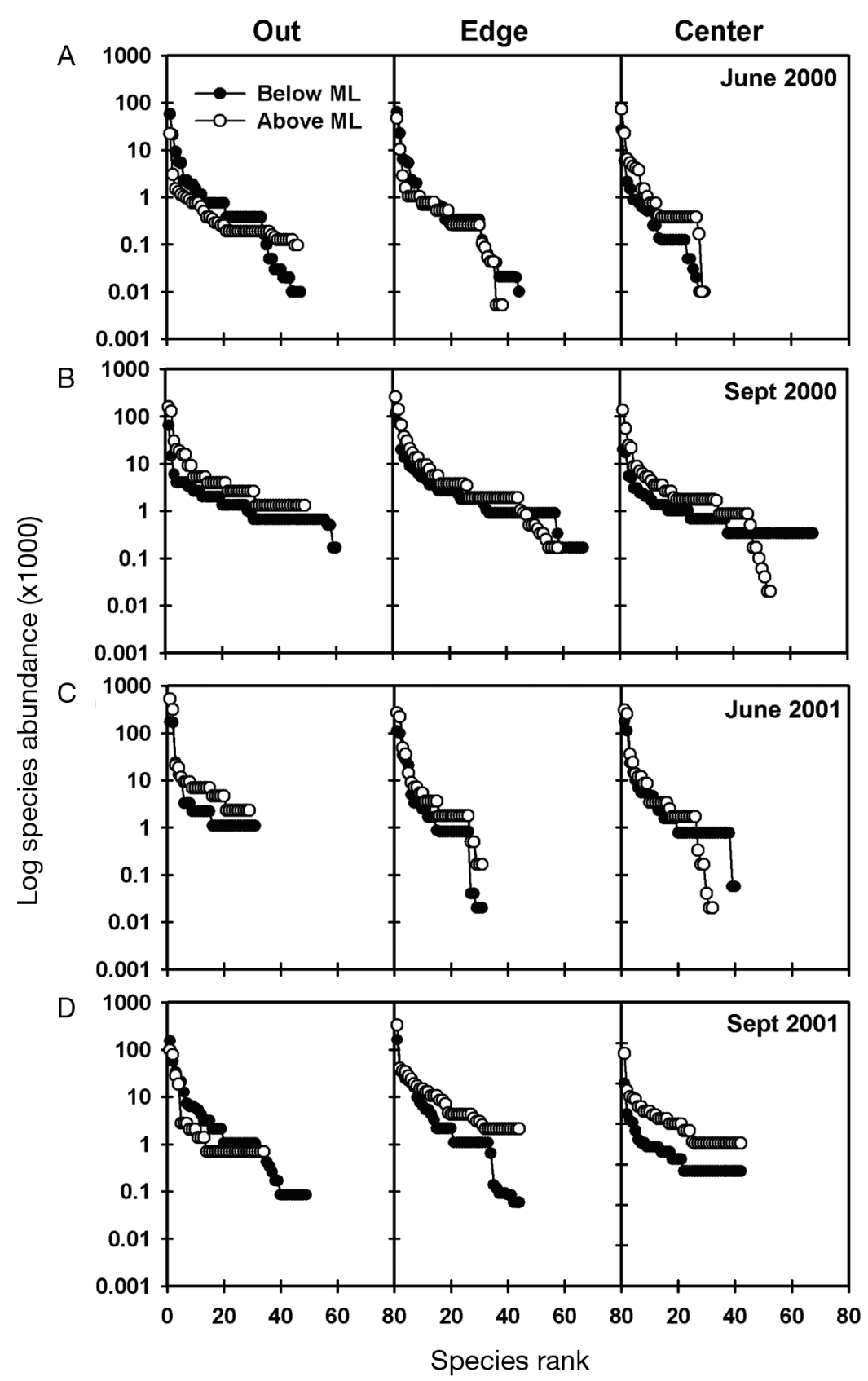

Fig. 7. Dominance-diversity curves based on log species abundance and species rank for (A) June 2000, (B) September 2000, (C) June 2001, and (D) September 2001 at outside, eddy edge and eddy center sites for depths below and above the mixed layer (ML)

\section{Spatial and temporal gradients in phytoplankton assemblages}

Changes in algal pigments, microscopic observations, and diversity reflected the spatial and temporal gradients of Haida-2000a as it drifted further away from the coast over a 20 mo period. Haida eddies (and other anticyclones in the GOA) differ from other eddies in eastern boundary current systems in that they drift into HNLC waters, where phytoplankton growth may become limited by low trace metal availability. Since the eddy was located in HNLC waters by this time, it is reasonable to hypothesize that low iron concentrations limited the survival of some species observed closer to the coast. Coastal-offshore gradients in species composition were observed both in the eddy and in its surroundings. Zeaxanthin - associated with cyanobacteria (Guillard et al. 1985) — and alloxanthin characteristic of Cryptophyceae (Gieskes Kraay 1983) - were found at higher concentrations closer to the coast, while they were nearly undetectable once the eddy had drifted offshore in Year 2 of evolution. Zeaxanthin, along with chl $b$ (associated with the Chlorophyceae, Prasinophyceae, and Euglenophyceae) and alloxanthin, are characteristically found within coastal assemblages (Jeffrey 1976) and have been observed in the transition zone between coastal and oceanic waters in the California Current (Chavez et al. 2000). Within the eddy, changes in species richness, diversity, and evenness of the phytoplankton assemblages were more closely related to seasonal differences than to the offshore gradient, with values observed in September exceeding those in June both in 2000 and 2001. All 3 metrics, however, displayed higher values in 2000 than in 2001 for the same sampling month. This seasonality in diversity metrics was not observed among the reference sites. Interestingly, the index values within the eddy exceeded those outside of it only in September when diversity was highest, perhaps indicating that eddies possess a greater capacity for diversity than do surrounding waters. This notion is consistent with satellite ocean color observations that show peaks in chl a within the eddy that are coincident with-but much larger than - peaks in the surrounding waters (S. A. Henson unpubl. data), suggesting that, when conditions are favorable to phytoplankton growth, eddies exhibit higher productivity than non-eddy waters.

The decline in coastal populations appeared to be slower within Haida-2000a than in the surrounding waters, despite the fact that significant horizontal and vertical mixing occurred during the winter (Peterson 2005). Over its lifetime an eddy is influenced by sev- 


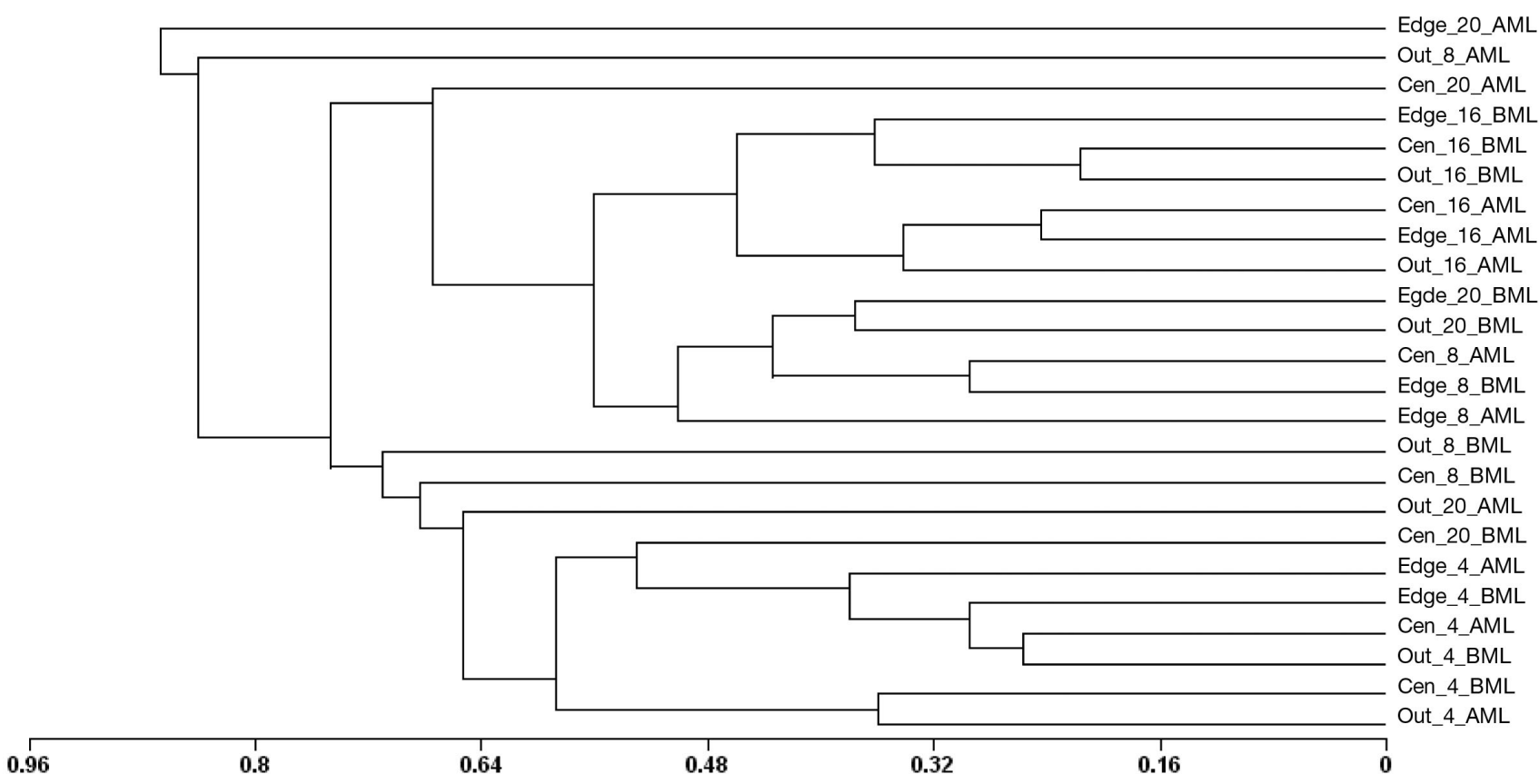

\section{Bray-Curtis distance}

Fig. 8. Dendrogram depicting agglomerative hierarchical clustering of the phytoplankton abundance data (all species included) constructed according to the sample site and based on the Bray-Curtis distance. Clustering was achieved using unweighted paired groups performed using arithmetic means (UPGMA). Sample numbers correspond to the eddy's age in months: $4=$ June 2000, 8 = September 2000, $16=$ June 2001, and $20=$ September 2001. Out $=$ outside the eddy, Edge $=$ the eddy edge, and Cen $=$ the eddy center. AML and BML = above and below the mixed layer, respectively

eral processes, some related to aging, others to physical phenomena such as frictional decay or interactions with other eddies (Fig. 9). In Haida-2000a, we observed the following sequence of events inferred from inter-cruise differences in biological and physical characteristics: (1) when the eddy lies close to the coast in winter/spring, entrainment into eddy circulation leads to offshore transport of coastal waters along the eddy's southern margin, as observed from satellite imagery. This facilitates the westward advection of coastal plankton. At the same time, oceanic waters are advected toward shore along the eddy's northern margin. Haida eddies are formed in winter, when relatively deep mixed layers are observed. Due to relatively deep mixed layers and low irradiance, primary productivity is low at the time of formation; (2) shoaling of the mixed layer in spring/summer and water column stabilization lead to stronger phytoplankton growth, resulting in nutrient depletion within the mixed layer; Haida eddies are characterized by sub-surface chlorophyll maxima; (3) as the eddy ages and drifts westward, frictional decay leads to isopycnal rebound and injection of nutrients into the mixed layer (see Crawford et al. 2007), stimulating phytoplankton growth; (4) eddy-eddy interactions modify the density structure of eddies and enhance the offshore transport of coastal species as these become entrained into the circulation of the older eddy.

The slow decline in the contribution to total phytoplankton by coastal species in eddies may be explained by the coalescence of a second, younger eddy with Haida-2000a between June and September 2001 (Peterson et al. 2005). This phenomenon likely resulted in the differences in algal assemblages observed at the eddy edge in 2001 and contributed to the presence of coastal plankton such as the Cryptophyceae within the eddy in Year 2. Furthermore, observations of freshwater diatom frustules (in Aulacoseira granulata) at the eddy edge in June 2001, as well as of unusual organisms such as the amoeboid Vexallifera sp. (Peterson 2005), indicated that the interaction among eddies preserves, in part, their continuity with coastal waters. Haida eddies may thus act to enhance offshore transport of coastal organisms, either via entrainment into peripheral eddy circulation near the surface, or by interactions among eddies of differing age, particularly when an eddy is formed adjacent to the continental margin (Fig. 9).

It is noteworthy that the contribution of phytoplankton to total carbon within the eddy was substantially 


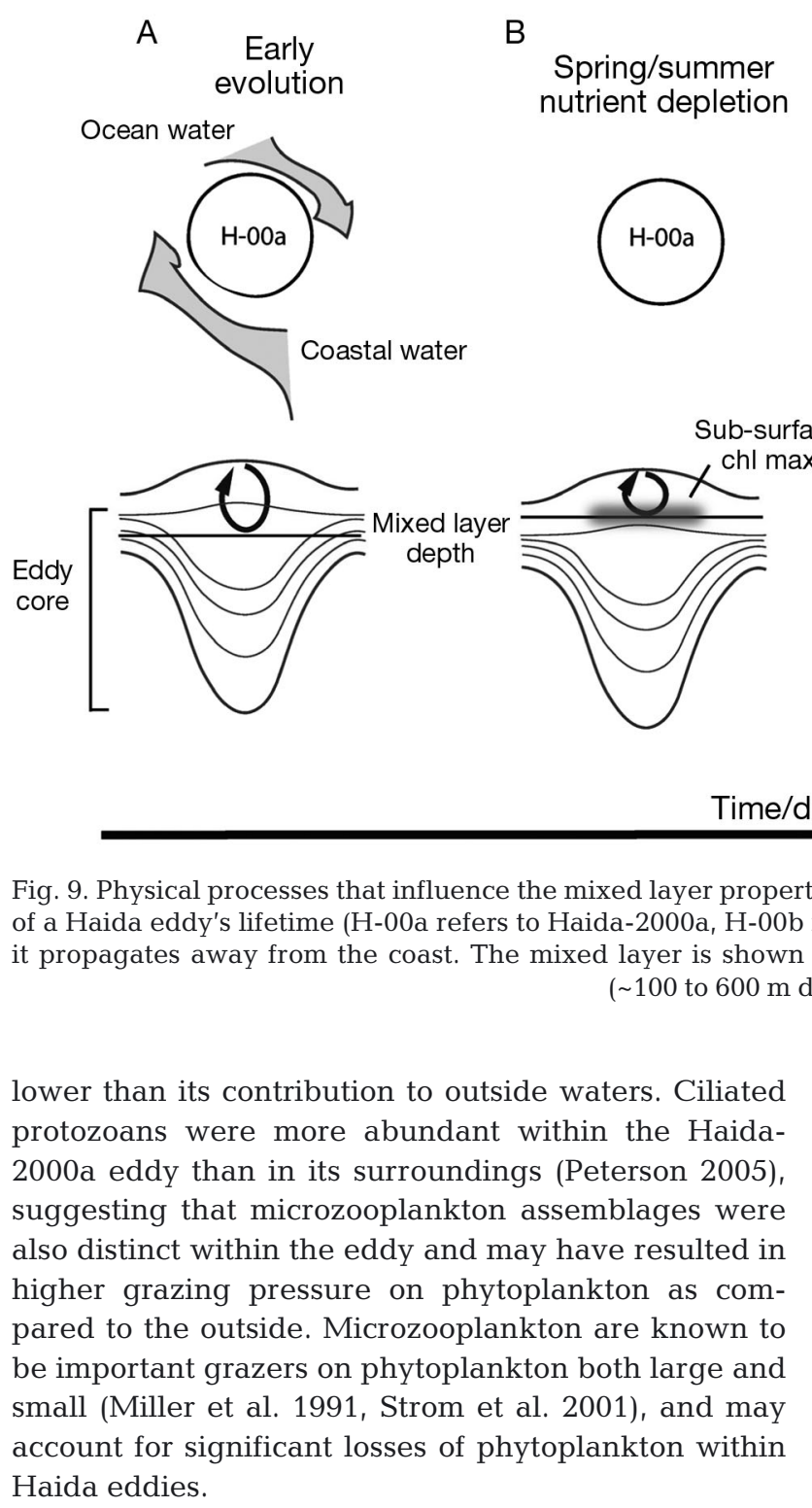

\section{Influences on the distribution of phytoplankton functional groups}

Following winter mixing between Years 1 and 2, macronutrients were restored within the surface waters of the eddy, while levels of iron remained low (Johnson et al. 2005). Similar to previous studies in the northeast subarctic Pacific, small cells dominated the phytoplankton assemblages throughout the study (Booth et al. 1982, Booth 1988). While the pigment data indicated that diatom growth was weak in Year 2, the microscopic examinations indicated that diatom cell abundance was quite high in Year 2, both in June and September. In June, the main siliceous taxon that proliferated was Nitzschia cylindriformis, a small $(<10 \mu \mathrm{m}$

tion. Previous studies showed that haptophytes and pelagophytes were important components of the nanoplankton in the Alaska Gyre, in contrast to the Western Subarctic Gyre where prasinophytes are often prevalent, and in the Bering Sea where diatoms tend to be dominant (Obayashi et al. 2001, Suzuki et al. 2002). In the northeast subarctic Pacific, a positive relationship between silicic acid and the abundance of Emiliania huxleyi (Putland et al. 2004) suggests that coccolithophores may outcompete diatoms under low-iron HNLC conditions. These observations are consistent with their reported ability to survive on low trace metal concentrations in the laboratory (Muggli \& Harrison 1996). Further, coccolithophores appear to be more abundant under El Niño conditions (Lipsen et al. 2007). We hypothesize that the increased contribution to total algal biomass by haptophytes (including coccolithophores) is related to their competitive ability under iron limitation, and that iron availability may play an important role in determining the prevalence of diatoms versus haptophytes, both in eddies and in their surroundings.

In addition to calcareous haptophytes, it is likely that, due to their small size and indistinct morphological characteristics, many of the 'nanoflagellates' not identified to species using light microscopy could have been members of the genus Phaeocystis. While no Phaeocystis colonies were observed in the samples examined microscopically during this study, the chemotaxonomically determined prevalence of haptophytes (including Phaeocystis) suggests that a substantial contribution may have been made by members of this important dimethyl-sulfide-producing algal genus. Previous work has shown that Phaeocystis colonies are easily destroyed by conventional preservatives (Rousseau et al. 1990), thus potentially precluding their detection among our samples. A further indication that Phaeocystis may have been present was the prevalence of the pigment 19'-but, which has been shown to be associated not only with the Pelagophyceae, but also with Phaeocystis pouchetti (Vaulot et al. 1994). An earlier study by Thibault et al. (1999) also discussed uncertainties in the identification of pelagophytes in the northeast subarctic Pacific, based on the overlap in pigment profiles between $P$. pouchetti and the pelagophytes. $P$. pouchetti can be very abundant in the northeast subarctic Pacific (Booth et al. 1982, Booth et al. 1993). It is quite possible that many of the 'nanoflagellates' included in the Pelagophyceae from this study were in fact Phaeocystis.

Coccolithophores are often prevalent later in the ecological succession of algal species when waters become more stratified and diatom growth becomes limited by low nutrient availability (Bidigare et al. 1990, Barlow et al. 1998). Interestingly, haptophytes were observed at the eddy center in June 2000, but not in the outside waters surrounding the eddy. The appearance of haptophytes in the near-surface, nutrient-depleted waters may have followed the decline of an earlier phytoplankton bloom within the eddy. In April 2000 a 10-fold enrichment of surface chl a over the surroundings was observed within the eddy by satellite imagery (Crawford et al. 2005). By the time of our sampling in June, chl a had declined in the surface waters of the eddy, and a subsurface pigment maximum was apparent. The subsurface pigment maximum was characterized by fewer haptophytes and more diatoms as compared to surface waters, suggesting a difference in conditions that supported haptophytes versus diatoms.

In Year 2 of evolution, a massive dust cloud originating in the Gobi and Taklamakan deserts traveled across the Pacific, spanning a region extending from the Hawaiian Islands to the Bering Sea. The trajectory was tracked using the Total Ozone Mapping Spectrometer (TOMS) aboard the Earth Probe satellite, and a comparison of the cloud with satellite altimetry placed it directly above the Haida-2000a eddy (Crispo et al. 2005). A dust deposition event was inferred from the decrease in airborne dust observed between April 13 and April 15, 2001. High-resolution observations provided by autonomous profiling floats deployed in the subarctic Pacific at Ocean Station Papa $\left(50^{\circ} \mathrm{N}\right.$, $145^{\circ} \mathrm{W}$ ) revealed a doubling of upper ocean POC in response to the dust event (Bishop et al. 2002). Therefore, it is possible that the input of iron to oceanic surface waters from the dust event stimulated phytoplankton growth in Haida-2000a just to the northeast of Station Papa. Large increases in biogenic silica were observed in the June 2001 samples from Haida-2000a, as compared to the previous year, yet chl a levels were the same or lower than in 2000 (Crispo et al. 2005). We suggest that excess biogenic silica, accompanied by only small changes in POC and chl $a$, were indicative of a senescing bloom of small diatoms with slow settling velocities. Studies of phytoplankton blooms and patterns of succession indicate that high levels of algal biomass can be maintained for several months, as has been seen, for example, on the Belgian coast (Rousseau et al. 2002). In that study, weekly sample collections from March to June 1995 revealed a succession of diatom species that varied in relation to their requirements for silicic acid, considered to be the limiting nutrient. At the same time, a 2 mo bloom of Phaeocystis co-occurred with the later diatom blooms. These observations are consistent with our hypothesis that our diatom bloom, which was followed by a succession from diatoms to haptophytes, was the result of a dust deposition event. Since Haida eddies can remain relatively intact over periods of several months during the 
spring and summer (Yelland \& Crawford 2005), it is possible that an April-May bloom could have been retained within the eddy as it drifted westward and could have given rise to a diatom-haptophyte succession, although significant cloud cover between May and July 2001 precluded the tracking of chl a associated with any potential iron-stimulated blooms. (See Crawford et al. [2005] for a time series of monthly composite images of chl a derived from satellite ocean color.) Since the westward propagation of mesoscale eddies is more rapid than the background flowwhich in this case follows the cyclonic circulation of the Alaska Gyre - a bloom contained within the eddy could conceivably travel away from its point of origin and drift into waters unaffected by the dust deposition event.

Notably, in June 2001, coccolithophores (including Calciopappus rigidus, Emiliania huxleyi, cf. Pleurochrysis carterae, and Syracosphaera spp.) were 3 times more abundant at the eddy and center sites than in the surrounding waters. In a 3 yr study, Lipsen et al. (2007) reported that coccolithophore abundance and productivity in the northeast subarctic Pacific can be much greater than previously recognized. Our data are consistent with the idea that calcifying organisms play an important role in the biological production in the eastern GOA, and that they may significantly influence the efficiency of the biological pump. Intriguingly, we also observed the calcifying dinoflagellate, Thoracosphaera heimii, in our study, particularly in Year 2. It is curious that calcareous plankton were in general much more prevalent in 2001 than in 2000, and that they included several taxa.

\section{Phytoplankton dynamics at eddy margins}

The data indicated that phytoplankton species composition in the high-velocity margin of a Haida eddy differed from that found in the center and in surrounding waters. Cluster analysis comparing assemblages among the different sites frequently revealed assemblage differences between the eddy edge and the center or outside (Fig. 8). Observations of size-fractionated chl a from the same cruises revealed that the contribution by small cells $(<5 \mu \mathrm{m}$ diam.) was consistently greater at the eddy edge than at the center or in the surroundings, particularly in September (in both years; Peterson 2005). We reconcile these differences by considering the physical processes that characterize eddy margins. Haida eddies do not develop streamers, as do the rings of the Gulf Stream (Garfield \& Evans 1987), but entrainment of coastal waters from the shelf can occur if the westward propagation away from the continental margin is sufficiently slow. Between April and
June 2000, satellite imagery indicated that warm coastal waters were being entrained into eddy circulation (Batten \& Crawford 2005). This represents an enhancing mechanism for offshore transport of plankton from the shelf. Consistent with the idea that shelf waters were being entrained via this mechanism, frustules of the freshwater diatom Aulacoseira granulata were observed at the edge and in waters just south of the edge in June 2000 (Peterson 2005). As indicated above, the coalescence of a second eddy with Haida2000a in summer 2001 influenced algal assemblages, resulting in assemblages at the eddy edge that differed from both the center and the surroundings. Owen (1980) pointed out that eddy edges can develop planktonic assemblages that are quite distinct from their surroundings due to the fact that ecological succession tends to proceed along rather than across streamlines. Any physical process that results in the isolation of a parcel of water will result in adjacent water masses with very different characteristics. Patchiness then results from the stirring of adjacent water parcels (Eckart 1948).

Whereas in June of both years the edges were influenced by advective circulation, in September of both years enhanced vertical mixing was observed there. This was reflected in vertical homogeneity in phytoplankton assemblages as well as in chl a (Crawford et al. 2005) and nutrient profiles (Peterson et al. 2005) similar to other frontal regions such as the Ensenada Front off southern California, where small vertical gradients in chl $a$ and nutrients accompany more vigorous physical mixing associated with the front (Haury et al. 1993). In the present study, a comparison of carbon:chl $a$ ratios required to reconcile the proportional contributions to total chl a by Synechococcus-type cyanobacteria (calculated using CHEMTAX and from microscopic counts) further suggested that the eddy edge was more homogeneously mixed than the eddy center, or than the waters surrounding the eddy. In order to achieve good agreement between microscopic counts and CHEMTAX, it was necessary to vary the carbon: chl a ratios substantially for samples collected below the surface, since this ratio is known to vary with light exposure (Geider 1987, Kana \& Glibert 1987). Based on literature values, we initially assumed that Synechococcus spp. had a carbon:chl a ratio of 150 (Liu et al. 1999). When we adjusted the carbon:chl a pigment ratios from 150 to 10-15 for samples below the mixed layer from June 2000, we achieved excellent agreement with the proportional contributions to total chl a as estimated by CHEMTAX, except at the eddy edge, where surface and subsurface carbon:chl $a$ ratios were held constant at 100 (data not shown). We interpret these differences as an indication that more vigorous mixing occurred at the eddy edge, since the light climate (and thus car- 
bon:chl a ratios) experienced by cells in the surface and deep waters should be more similar when mixing is stronger. It is important to note, however, that the primary pigment used to quantify the contribution of Synechococcus to total chl a is zeaxanthin, which is also present in the prasinophytes, chlorophytes, and chrysophytes, although none of these groups were estimated to make a significant contribution to total chl a using the full characteristic pigment suite, and they all possess lower zeaxanthin:chl a ratios when compared to Synechococcus spp. (Mackey et al. 1997).

\section{SUMMARY}

Phytoplankton assemblages within Haida-2000a and in its surrounding waters differed over time and with distance from the continental shelf, becoming less coastal and more oceanic in character between the first and second years of evolution. Phytoplankton diversity in the eddy was greater in September than in June during both years of observation, and the ShannonWiener index values tended to decrease with distance offshore. Phytoplankton assemblages in the eddy were more diverse than those outside the eddy in September, when overall diversity levels were highest. The interaction of Haida-2000a with a second, younger eddy allowed coastal species to persist within the eddy as it propagated offshore. Assemblages at the eddy edge reflected the entrainment of coastal waters associated with anticyclonic circulation and they exhibited more uniform vertical distribution, likely due to local upwelling. Observations of unique pigment signatures in the eddy potentially associated with a dust deposition event or the differential response to vertical mixing between Haida-2000a and its surroundings suggest that, in the Gulf of Alaska, Haida eddies may respond differently to external forcing as compared to non-eddy waters.

Acknowledgements. The authors thank the captain and crew of the CCGS 'John P. Tully', as well as the chief scientists for the scientific cruises. In addition, we gratefully acknowledge the assistance of H. McLean, J. Putland, and E. Borhnold in sampling at sea, as well as scientific input from F. Whitney (Institute of Ocean Sciences, Sidney, BC). L. Miller kindly provided the POC data. Funding was provided through a Fisheries and Oceans Canada grant to P.J.H. and a National Science and Engineering Research Council of Canada grant to T.D.P. This research was supported in part through National Science Foundation cooperative agreement OCE-0424602.

\section{LITERATURE CITED}

Andersen RA, Saunders GW, Paskind MP, Sexton JP (1993) Ultrastructure and 18S RNA gene sequence for Pelagomonas calceolata gen. et sp. nov. and the description of a new algal class, the Pelagophyceae classis nov. J Phycol 29:701-715

Barlow RG, Mantoura RFC, Cummings DG, Pond DW, Harris RP (1998) Evolution of phytoplankton pigments in mesocosm experiments. Estuar Coast Shelf Sci 46:15-22

Batten SD, Crawford WR (2005) The influence of coastal origin eddies on oceanic plankton distributions in the eastern Gulf of Alaska. Deep-Sea Res II 52:991-1010

Beklemishev CW, Nakonechnaya AP (1972) Plankton of the North Pacific current. In: Takenouti AY (ed) Biological oceanography of the northern North Pacific. Idemitsu Shoten, Tokyo, p 367-371

> Benitez-Nelson CR, Bidigare RR, Dickey TD, Landry MR and others (2007) Mesoscale eddies drive increased silica export in the subtropical Pacific Ocean. Science 316: 1017-1021

Bidigare RR, Marra J, Dickey TD, Iturriaga R, Baker KS, Smith RC, Pak H (1990) Evidence for phytoplankton succession and chromatic adaptation in the Sargasso Sea during spring 1985. Mar Ecol Prog Ser 60:113-122

Bishop JKB, Davis RE, Sherman JT (2002) Robotic observations of dust storm enhancement of carbon biomass in the North Pacific. Science 298:817-821

Booth BC (1988) Size classes and major taxonomic groups of phytoplankton at two locations in the subarctic Pacific Ocean in May and August, 1984. Mar Biol 97:275-286

> Booth BC, Lewin J, Norris RE (1982) Nanoplankton species predominant in the subarctic Pacific in May and June 1978. Deep-Sea Res I 29:185-200

Booth BC, Lewin J, Postel JR (1993) Temporal variation in the structure of autotrophic and heterotrophic communities in the subarctic Pacific. Prog Oceanogr 32:57-99

Boyd PW, Strom S, Whitney FA, Doherty S and others (1995) The NE subarctic Pacific in winter: I. Biological standing stocks. Mar Ecol Prog Ser 128:11-24

> Bray JR, Curtis JT (1957) An ordination of the upland forest communities of southern Wisconsin. Ecol Monogr 27: 325-349

> Brickley PJ, Thomas AC (2004) Satellite-measured seasonal and inter-annual chlorophyll variability in the northeast Pacific and coastal Gulf of Alaska. Deep-Sea Res II 51: 229-245

Buesseler KO, Lamborg CH, Boyd PW, Lam PJ and others (2007) Revisiting carbon flux through the ocean's twilight zone. Science 316:567-570

Chavez FP, Michisaki RP, Friederich GE, Pennington JT and others (2000) A ten-year time series from Monterey Bay, California: seasonal, interannual and long-term patterns. www.mbari.org/bog/projects/centralcal/intro.htm

Clemons MJ, Miller CB (1984) Blooms of large diatoms in the oceanic, subarctic Pacific. Deep-Sea Res I 31:85-95

Coale KH, Johnson KS, Chavez FP, Buesseler KO and others (2004) Southern ocean iron enrichment experiment: carbon cycling in high- and low-Si waters. Science 304: 408-414

Crawford WR (2002) Physical characteristics of Haida eddies. J Oceanogr 58:703-713

Crawford WR, Cherniawsky JY, Foreman MGG, Gower JFR (2002) Formation of the Haida-1998 oceanic eddy. J Geophys Res 107:3069

> Crawford WR, Brickley PJ, Peterson TD, Thomas AC (2005) Biological impact of Haida eddies in the eastern Gulf of Alaska, based on SeaWiFS and satellite altimetry observations. Deep-Sea Res II 52:975-990

Crawford WR, Brickley PJ, Thomas AC (2007) Mesoscale eddies dominate surface phytoplankton in northern Gulf of Alaska. Prog Oceanogr 75:287-303 
Crispo SM, Peterson TD, Lohan MC (2005) Implications of an Asian dust storm on the Gulf of Alaska. Sea Technol 46: 29-37

> Di Lorenzo E, Foreman MGG, Crawford WR (2005) Modelling the generation of Haida eddies. Deep-Sea Res II 52: 853-873

> Dortch Q, Maske H (1982) Dark uptake of nitrate and nitrate reductase activity of a red-tide population off Peru. Mar Ecol Prog Ser 9:299-303

Eckart C (1948) An analysis of the stirring and mixing processes in incompressible fluids. J Mar Res 7:265-275

> Eppley RW, Reid FMH, Cullen JJ, Winant CD, Stewart E (1984) Subsurface patch of a dinoflagellate (Ceratium tripos) off Southern California: patch length, growth rate, associated vertically migrating species. Mar Biol 80: 207-214

Falkowski PG, Katz ME, Knoll AH, Quigg A, Raven JA, Schofield O, Taylor FJR (2004) The evolution of modern eukaryotic phytoplankton. Science 305:354-360

Francois R, Honjo S, Krishfield R, Manganini S (2002) Factors controlling the flux of organic carbon to the bathypelagic zone of the ocean. Global Biogeochem Cycles 16:1087, doi:10.1029/2001GB001722

> Fryxell GA, Gould RW, Balmori ER, Theriot EC (1985) Gulf Stream warm core rings: phytoplankton in two fall rings of different ages. J Plankton Res 7:339-364

Fukumori I (1992) Meridional circulation and mixing associated with the decay of warm-core ring 82B. Deep-Sea Res 39(Suppl 1):S45-S65

Garfield N, Evans DL (1987) Shelf water entrainment by Gulf Stream warm-core rings. J Geophys Res 92:13 003-13 012

Geider RJ (1987) Light and temperature dependence of the carbon to chlorophyll-a ratio in microalgae and cyanobacteria: implications for physiology and growth of phytoplankton. New Phytol 106:1-34

Gould RW, Fryxell GA (1988) Phytoplankton species composition and abundance in a Gulf Stream warm core ring. I. Changes over a five-month period. J Mar Res 46:399-428

Gower JFR (1997) Bright plankton blooms on the west coast of North America observed with AVHRR imagery. In: Kahru M, Brown CW (eds) Monitoring algal blooms: new techniques for detecting large-scale environmental change, Chapter 2. Landes Bioscience. Springer Verlag, New York, NY, p 25-41

Greene RM, Geider RJ, Kolber Z, Falkowski PG (1992) Ironinduced changes in light harvesting and photochemical energy conversion processes in eukaryotic marine algae. Plant Physiol 100:565-575

Guillard RRL, Murphy LS, Foss P, Liaaenjensen S (1985) Synechococcus spp. as likely zeaxanthin-dominant ultraphytoplankton in the North Atlantic. Limnol Oceanogr 30: 412-414

Hansen C, Kvaleberg E, Samuelsen A (2010) Anticyclonic eddies in the Norwegian Sea: their generation, evolution and impact on primary production. Deep-Sea Res I 57: 1079-1091

> Harrison PJ (2002) Station Papa time series: insights into ecosystem dynamics. J Oceanogr 58:259-264

Hasle GR, Booth BC (1984) Nitzschia cylindriformis sp. nov., a common and abundant nanoplankton diatom of the eastern subarctic Pacific. J Plankton Res 6:493-503

Haury LR, Venrick EL, Fey CL, McGowan JA, Niiler PP (1993) The Ensenada Front: July 1985. CCOFI Rep 34:69-88

Henson SA, Thomas AC (2008) A census of oceanic anticyclonic eddies in the Gulf of Alaska. Deep-Sea Res I 55: 163-176

> Hitchcock GL, Langdon C, Smayda TJ (1985) Seasonal variations in the phytoplankton biomass and productivity of a warm-core Gulf Stream ring. Deep-Sea Res I 32: $1287-1300$

Hitchcock GL, Langdon C, Smayda TJ (1987) Short-term changes in the biology of a Gulf Stream warm-core ring: phytoplankton biomass and productivity. Limnol Oceanogr 32:919-928

Jeffrey SW (1976) A report of green algal pigments in central North Pacific ocean. Mar Biol 37:33-37

Jeffrey SW, Hallegraeff GM (1987) Phytoplankton pigments, species and light climate in a complex warm-core eddy of the East Australian Current. Deep-Sea Res 34: 649-673

Jeffrey SW, Vesk M (2005) Introduction to marine phytoplankton and their pigment signatures. In: Jeffrey SW, Mantoura RFC, Wright SW (eds) Phytoplankton pigments in oceanography. UNESCO, Paris, p 37-84

Jeffrey SW, Wright SW (1997) Qualitative and quantitative analysis of SCOR reference algal cultures. In: Jeffrey SW, Mantoura RFC, Wright SW (eds) Phytoplankton pigments in oceanography: guidelines to modern methods. SCORUNESCO, Paris

Johnson WK, Miller LA, Sutherland NE, Wong CS (2005) Iron transport by mesoscale Haida eddies in the Gulf of Alaska. Deep-Sea Res II 52:933-953

> Kana TM, Glibert PM (1987) Effect of irradiances up to 2000 $\mu \mathrm{E} \mathrm{m} \mathrm{m}^{-2} \mathrm{~s}^{-1}$ on marine Synechococcus WH7803-11: photosynthetic responses and mechanisms. Deep-Sea Res I 34: 497-516

> Lipsen MS, Crawford DW, Gower J, Harrison PJ (2007) Spatial and temporal variability in coccolithophore abundance and production of PIC and POC in the NE subarctic Pacific during El Niño (1998), La Niña (1999) and 2000. Prog Oceanogr 75:304-325

> Liu H, Bidigare RR, Laws E, Landry MR, Campbell L (1999) Cell cycle and physiological characteristics of Synechococcus (WH7803) in chemostat culture. Mar Ecol Prog Ser 189:17-25

Mackas DL, Tsurumi M, Galbraith MD, Yelland DR (2005) Zooplankton distribution and dynamics in a North Pacific eddy of coastal origin: II. Mechanisms of eddy colonization by and retention of offshore species. Deep-Sea Res II 52: 1011-1036

> Mackey MD, Mackey DJ, Higgins HW, Wright SW (1996) CHEMTAX - a program for estimating class abundance from chemical markers: application to HPLC measurements of phytoplankton. Mar Ecol Prog Ser 144:265-283

Mackey MD, Higgins HW, Mackey DJ, Wright SW (1997) CHEMTAX user's manual: a program for estimating class abundances from chemical markers-application to HPLC measurements of phytoplankton pigments. Report No. 229, CSIRO Marine Laboratories, Hobart

> Martin JH, Fitzwater SE (1988) Iron deficiency limits phytoplankton growth in the north-east Pacific subarctic. Nature 331:341-343

> McGillicuddy DJ, Robinson AR (1997) Eddy-induced nutrient supply and new production in the Sargasso Sea. Deep-Sea Res I 44:1427-1450

Menden-Deuer S, Lessard EJ (2000) Carbon to volume relationships for dinoflagellates, diatoms, and other protist plankton. Limnol Oceanogr 45:569-579

Miller CB, Frost BW, Wheeler PA, Landry MR, Welschmeyer N, Powell TM (1991) Ecological dynamics in the subarctic Pacific, a possibly iron-limited ecosystem. Limnol Oceanogr 36:1600-1615

Miller LA, Robert M, Crawford WR (2005) Editorial: the large, westward-propagating Haida eddies of the Pacific eastern boundary. Deep-Sea Res II 52:845-852 
Millero FJ, Poisson A (1981) International one-atmosphere equation of state of sea water. Deep-Sea Res 28:625-629

Muggli DL, Harrison PJ (1996) Effects of nitrogen source on the physiology and metal nutrition of Emiliania huxleyi grown under different iron and light conditions. Mar Ecol Prog Ser 130:255-267

Obayashi Y, Tanoue E, Suzuki K, Handa N, Nojiri Y, Wong CS (2001) Spatial and temporal variabilities of phytoplankton community structure in the northern North Pacific as determined by phytoplankton pigments. Deep-Sea Res I 48:439-469

Owen RW (1980) Eddies of the California Current System: physical and ecological characteristics. In: Power, DM (ed) The California islands: proceedings of a multidisciplinary symposium. Santa Barbara Museum of Natural History, Santa Barbara, CA, p 237-263

Parsons TR, Takahashi M (1973) Environmental control of phytoplankton cell size. Limnol Oceanogr 18:511-515

Pena MA, Varela DE (2007) Seasonal and interannual variability in phytoplankton and nutrient dynamics along Line $\mathrm{P}$ in the NE subarctic Pacific. Prog Oceanogr 75: 200-222

Peterson TD (2005) Studies on the biological oceanography of Haida eddies. PhD thesis, University of British Columbia, Vancouver

Peterson TD, Whitney FA, Harrison PJ (2005) Macronutrient dynamics in an anticyclonic mesoscale eddy in the Gulf of Alaska. Deep-Sea Res II 52:909-932

Putland JN, Crawford DW, Whitney FA (2004) Survey of bottom-up controls on the distribution of Emiliania huxleyi in the northeast subarctic Pacific. Deep-Sea Res I 51: 1793-1802

Ribalet F, Marchetti A, Hubbard KA, Brown K and others (2010) Unveiling a phytoplankton hotspot at a narrow boundary between coastal and offshore waters. Proc Natl Acad Sci USA 107:16571-16576

Rodriguez F, Varela M, Fernandez E, Zapata M (2003) Phytoplankton and pigment distributions in an anticyclonic slope water oceanic eddy (SWODDY) in the southern Bay of Biscay. Mar Biol 143:995-1011

Rousseau V, Mathot S, Lancelot C (1990) Calculating carbon biomass of Phaeocystis sp. from microscopic observations. Mar Biol 107:305-314

Rousseau V, Leynaert A, Daoud N, Lancelot C (2002) Diatom succession, silicification and silicic acid availability in Belgian coastal waters (Southern North Sea). Mar Ecol Prog Ser 236:61-73

Strathmann RR (1967) Estimating the organic carbon content of phytoplankton from cell volume or plasma volume. Limnol Oceanogr 12:411-418

Strom SL, Brainard MA, Holmes JL, Olson MB (2001) Phytoplankton blooms are strongly impacted by microzooplankton grazing in coastal North Pacific waters. Mar Biol 138: 355-368

Sun J, Liu D (2003) Geometric models for calculating cell biovolume and surface area for phytoplankton. J Plankton Res 25:1331-1346

Suzuki R, Ishimaru T (1992) Characteristics of photosynthetic

Editorial responsibility: Katherine Richardson,

Copenhagen, Denmark pigment composition of Gymnodinium mikimotoi Miyake et Kominami ex Oda. J Oceanogr 48:367-375

Suzuki K, Minami C, Liu HB, Saino T (2002) Temporal and spatial patterns of chemotaxonomic algal pigments in the subarctic Pacific and the Bering Sea during the early summer of 1999. Deep-Sea Res II 49:5685-5704

Taylor FJR, Waters RE (1982) Spring phytoplankton in the subarctic North Pacific ocean. Mar Biol 67:323-335

> Thibault D, Roy S, Wong CS, Bishop JK (1999) The downward flux of biogenic material in the NE subarctic Pacific: importance of algal sinking and mesozooplankton herbivory. Deep-Sea Res II 46:2669-2697

Tréguer P, Pondaven P (2000) Global change: silica control of carbon dioxide. Nature 406:358-359

Utermöhl H (1958) Zur Vervollkommnung der quantiativen Phytoplankton-Methodik. Mitt Int Ver Theor Angew Limnol 9:1-38

> Varela DE, Harrison PJ (1999) Seasonal variability in nitrogenous nutrition of phytoplankton assemblages in the northeastern subarctic Pacific Ocean. Deep-Sea Res II 46: 2505-2538

> Vaulot D, Birrien JL, Marie D, Casotti R, Veldhuis MJW, Kraay GW, Chretiennot-Dinet MJ (1994) Morphology, ploidy, pigment composition, and genome size of cultured strains of Phaeocystis (Prymnesiophyceae). J Phycol 30: 1022-1035

Verardo DJ, Froelich PN, McIntyre A (1990) Determination of organic carbon and nitrogen in marine sediments using the Carlo Erba NA-1500 analyzer. Deep-Sea Res 37: 157-165

> Verity PG, Smetacek V (1996) Organism life cycles, predation, and the structure of marine pelagic ecosystems. Mar Ecol Prog Ser 130:277-293

Vesk M, Jeffrey SW (1987) Ultrastructure and pigments of two strains of the picoplanktonic alga Pelagococcus subviridis (Chrysophyceae). J Phycol 23:322-336

Whitney FA, Freeland HJ (1999) Variability in upper-ocean water properties in the NE Pacific Ocean. Deep-Sea Res II 46:2351-2370

Whitney FA, Wong CS, Boyd PW (1998) Interannual variability in nitrate supply to surface waters of the Northeast Pacific Ocean. Mar Ecol Prog Ser 170:15-23

- Whitney FA, Crawford DW, Yoshimura T (2005) The uptake and export of silicon and nitrogen in HNLC waters of the NE Pacific Ocean. Deep-Sea Res II 52:1055-1067

> Wong CS, Crawford DW (2006) Evolution of phytoplankton pigments in an in-situ iron enrichment experiment in the subarctic NE Pacific. Deep-Sea Res II 53:2152-2167

Wong CS, Whitney FA, Crawford DW, Iseki K, Matear RJ, Johnson WK, Page JS (1999) Seasonal and interannual variability in particle fluxes of carbon, nitrogen and silicon from time series of sediment traps at Ocean Station $\mathrm{P}$, 1982-1993: relationship to changes in subarctic primary productivity. Deep-Sea Res II 46:2735-2760

Yelland DR, Crawford WR (2005) Currents in Haida eddies. Deep-Sea Res II 52:875-892

> Yool A, Tyrrell T (2003) Role of diatoms in regulating the ocean's silicon cycle. Global Biogeochem Cycles 17:1103

Submitted: July 7, 2010; Accepted: November 19, 2010

Proofs received from author(s): February 7, 2011 